\title{
Yanal Yüklü Eğik Rijit Kazıkların Sayısal Analizi
}

\author{
Gizem MISIR ${ }^{1}$ \\ Mustafa LAMAN ${ }^{2}$
}

\section{ÖZ}

Yanal yük etkisindeki kısa kazık çekme kapasitesi, kazığın homojen/tabakalı kum zeminler içerisine, düşey/eğik olarak yerleştirilmesi durumlarında, laboratuvar model deneyleri ve sayısal analizler ile araştırılmıştır. Öncelikle problem 3 boyutlu olarak analiz edilmiş, ardından sistemin 2 boyuta indirgenebilir olup olmadığ 1 araştırılmıştır. Bu amaçla, yanal yük etkisindeki rijit kazık problemi, şerit yük altındaki rijit bir duvar problemine dönüştürülmüştür. Problemin boyut değiştirmesi ile deney sonuçları ve 2 boyutlu sayısal analiz sonuçları arasında oluşan mertebe farkı, sabit katsayılar kullanılarak aşılmıştır. Geoteknik mühendisliği alanında ilk defa kullanılan 3 boyutlu bir problemin 2 boyuta indirgenmesi yaklaşımı ile, kabul edilebilir doğrulukta sonuçlar elde edilmiştir.

Anahtar Kelimeler: Yanal yük, eğik kısa kazık, tabakalı zemin, sayısal analiz, plaxis.

\begin{abstract}
Numerical Analysis of Laterally Loaded Battered Rigid Piles

The short pile pulling capacity under the lateral load was investigated by both laboratory model tests and numerical analysis in the case of vertical/inclined placement in homogeneous/layered sandy soils. Firstly, the problem was analyzed in 3-dimensional form and then it was investigated whether the problem could be reduced to 2-dimensional condition. For this purpose, the problem of a rigid pile under a single lateral load was transformed into a rigid wall problem under a strip load. The difference which occurred because of the dimensional variation of the problem between the results of the experimental studies and the results of 2-D numerical analysis was overcome by using constant coefficients. With the 2-D reduction approach of a 3-D problem, which was used for the first time in the field of geotechnical engineering, results were obtained with acceptable accuracy.
\end{abstract}

Keywords: Lateral load, short battered pile, layered soil, numerical analysis, plaxis.

Not: Bu yaz1

- Yayın Kurulu'na 1 Mart 2018 günü ulaşmıştır. 9 Ekim 2018 günü yayımlanmak üzere kabul edilmiştir.

- 30 Kasım 2019 gününe kadar tartışmaya açıktır.

- https://dx.doi.org/10.18400/tekderg.399961

1 Karamanoğlu Mehmetbey Üniversitesi, İnşaat Mühendisliği Bölümü, Karaman - gmisir@kmu.edu.tr https://orcid.org/0000-0002-2649-0381

2 Liverpool Üniversitesi, İnşaat Mühendisliği Bölümü, İngiltere - lamanmustafa@gmail.com https://orcid.org/0000-0003-2914-7738 


\section{GíRiş}

Kazık temeller, kazığa etkiyen yükün doğrultu ve şiddetine göre, düşey ve yatay yüklü olmak üzere iki sınıfa ayrılmaktadır. Düşey yükler, kazık eksenine paralel olarak etkirken, yatay yükler kazık eksenine dik yönde ortaya çıkabildiği gibi, yapıdan kazığa aktarılan kesme kuvvetleri ve moment kesit tesirleri de yatay yükler oluşturmaktadır. Kazığa etkiyen tüm yüklerin güvenli bir şekilde zemine aktarılarak, kazık malzemesi ve kesiti ile güvenli bir şekilde taşınması gerekmektedir. Kazığa etkiyen yanal yük bileşeninin büyüklüğüne göre, kazıklar zemin içerisine düşey veya eğimli olarak inşa edilmektedir. Üstyapı yükü yatay bileşeninin küçük olduğu durumlarda yükler, düşey kazıklarla güvenle taşınabilmektedir. Bununla birlikte; rıhtım ve dalgakıranların kazıkları, köprü ayaklarının kazıklı temelleri, petrol arama kule ve vinçlerinin kazıklı temelleri, yüksek baca yapılarının temelleri ve dayanma yapıları gibi yapıların kazıklı temelleri, oldukça yüksek mertebelerdeki yatay yük bileşenleri etkisinde kalabilmektedir. Bu yükler göz önüne alınmaksızın, tasarlanıp inşa edilen düşey kazıkların, üst yapı yüklerini güvenli şekilde taşımaları olanaksızdır. Düşey kazıkların taşıma gücü açısından yetersiz kaldığı durumlarda, eğik kazıklar inşa edilerek, yüksek yatay taşıma gücü sağlanabilmektedir. Literatürdeki çalışmalar incelendiğinde, yanal yüklü kazık davranışının analizinde yaygın olarak kullanılan tasarım yöntemleri, sınır durum, temel zemini reaksiyon yöntemi, p-y eğrileri ve elastik analiz yöntemleridir. Bir kazığın tahmini nihai yanal yük taşıma kapasitesi en basit yaklaşımla, serbest başlı bir kazığın statik dengesini göz önüne alarak, yatay kuvvet ve momentlerin dengesi kullanılarak ortaya çıkan denklemlerin çözülmesi ile hesaplanabilir. Çözümlemeler; zemin direncinin derinlik boyunca üniform olduğu, derinlik ile beraber doğrusal olarak arttığ 1 ve derinlik ile beraber non-lineer olarak değiştiği durumlar olmak üzere farklı zemin direnci dağılımları için elde edilmiştir (Poulos ve Davis, 1980) [1]. Günümüzde en yaygın şekilde kullanılan sınır durum yöntemleri Brinch-Hansen (1961) [2] ve Broms (1964a-b) [3 ve 4] tarafından önerilmiş olan yöntemlerdir.

Temel zemini reaksiyon yöntemi ve p-y eğri yöntemi elastik zemine oturan kiriş kabulünü kullanmaktadır. Belirtilen yöntemler, basit olmaları ve uygun doğrulukta sonuçlar vermeleri nedenleri ile yaygın bir kullanım alanına sahiptir. p-y eğri yöntemi; kazığı elastik bir eleman olarak, zemini de non-lineer özellik gösteren bir seri yay olarak modellemektedir. Elastik analiz yönteminde ise zemin homojen, izotrop ve elastik davranış özelliğine sahip sürekli bir ortam olarak kabul edilmektedir. Eğer zemin kütlesi içerisinde tamamıyla elastik şartlar hakim ise, kazık uzunluğu boyunca kazığın ve zeminin yatay deplasmanları birbirine eşit olacaktır. Zeminin lineer elastik özellikte sürekli bir ortam olarak kabul edildiği bu yaklaşımda; kazık ve zemin ortamı ayrı ayrı analiz edilir ve iteratif bir işlem uygulanarak kazık-zemin ara yüzeyi boyunca kazık ve zemin için elde edilmiş olan ötelenme ve basınç değerlerinin birbiri ile eşleşmesi sağlanır.

Yüksek yatay yüklere karşı koymak için kazıkların zemin içerisine eğik olarak yerleştirilmeleri durumunda, bu kazıkların yatay yükler etkisindeki davranışlarını araştıran literatürdeki çalışma sayısı hala yetersizdir. Zomorodian ve Dehghan (2011) [5] keçe parçaları ile zemin karışımından oluşan geri dolgu malzemesi ile güçlendirilen kumlu şev civarında yerleştirilen kazığın, yanal yük altındaki davranışını incelemek için 50 adet deneysel çalışma yapmışlardır. Güçlendirme yapılmadan hazırlanan deney sonuçları karşılaştırma amaçlı tutularak, keçe oranı, keçe parçalarının içeriği, kazığın şev tepesine olan mesafesi, kumun rölatif sıkılığı, şev açısı, kazık gömülü uzunluğu ve kazık kesitinin etkisini, 
dayanım gelişme oranı (LRIR) parametresi üzerinden araştırmışlardır. Kazığın 7D mesafeden daha uzağa yerleştirilmesi durumunda şev etkisi ortadan kalkarken, iyileştirmede en büyük yarar, kazığın tam şev tepesine yerleştirilmesi durumunda elde edilmiştir. Donatılı durumda min. LRIR katkı yoğunluğunun 0.3 ve yaprak şekil boyutunun 1 olduğu durumda, LRIR değerinin maksimum olduğu durum ise, katkı yoğunluğunun 1.5 ve yaprak şekil boyutunun 3 olduğu durumda elde edilmiştir. Kazık gömülü uzunluğunun ve rölatif sıkılığın artması, şev açısının ve kazık yüzey pürüzsüzlüğünün azalması ile, hem güçlendirilmiş, hem de güçlendirilmemiş durumda kazığın yanal dayanımında artışa neden olmuştur. Güçlendirme malzemesi gevşek kum zeminde küçük bir artışa neden olmasına rağmen, zemin koşulları sıkı olduğunda, LRIR değerinde belirgin bir artış elde edilmiştir. Helm ve Suleiman (2012) [6] yanal yüklü kazık ve zemin arasındaki ara yüz davranışını (SSI) araştırmak için deneysel çalışmalar yapmışlardır. Deneylerde doğrudan ve dolaylı yollardan yükleme farkını görebilmek için iki farklı deney kasası oluşturulmuştur. Kazık ve zemin arasındaki ara yüz davranışını belirleyebilmek için, gerinim pulları, levha basınç sensörleri, dijital görüntüleme teknikleri ve SAA yöntemi ile kazık boyunca ölçümler yapılmıştır. Çalışma için 3 farklı deney yapılmıştır. Bunlar; doğrudan yükleme, dolaylı yollardan yükleme ve dolaylı yollardan yükleme durumuna paralel olarak zemin içerisinde kazığın olmadığı durumdur. Doğrudan yüklemede 1.7 kN'luk yük altında, kazık ucu, ilk durumuna göre $52.7 \mathrm{~mm}$ hareket ederken dolaylı olarak yapılan yükleme deneylerinde ise, kasanın hareketli parçasına dişardan uygulanan 17.8 kN'luk yük altında kasa $122.6 \mathrm{~mm}$, kazık ise $69.7 \mathrm{~mm}$ hareket etmiştir. Sonuç olarak, dijital görüntüleme sistemleri ve ölçüm ekipmanlarıyla zemin ile kazık arasındaki etkileşimin detaylı olarak incelenebildiği gösterilmiştir. Rahimi ve Bargi (2010) [7] sıkı kum içerisinde yer alan, 21 adet düşey ve 4 adet eğik kazıktan oluşan rıhtım temellerinin davranışını 3D ABAQUS programı ile araştırmışlardır. Eğik kazık pozisyonunu ve eğiminin etkisini araştırmak için yapılan sayısal analizler, kazık başına uygulanan 15.000 kN'luk yatay yük altında gerçekleştirilmiştir. Analizler sonucunda, tüm kazıkların düşey olduğu konfigürasyon içerisinde, yüke en yakın sırada yer alan kazıkların uygulanan toplam yükün, \%33'ünü taşıdığ görülmüştür. Kazıkların eğik yerleşiminin yaratacağı etkiyi incelemek için, $15^{\circ}, 20^{\circ}, 25^{\circ}$ ve $30^{\circ}$ 'lik kazık açılarında analizler yapılmış ve kazık açısının artmasıyla, kazık başında meydana gelen deformasyonlarda azalmalar görülmüştür. Kazık sıralarına düşen yanal yük incelendiğinde ise, kazık yerleşim açısının artması ile eğik kazıklar tarafından taşınan yük değerleri de belirgin bir şekilde artmaktadır. Vu ve ark. (2016 ve 2017) [8 ve 9] eğik kazıkların bulunduğu ve bulunmadığı grup kazılar ve kazıklı radye temellerin yanal yük altındaki davranışları ve dayanım mekanizmalarını hem model deney çalışmaları hem de sayısal analizler ile araştırmışlardır. Eğik kazık barındıran temellerin, sadece düşey kazıklardan oluşan temel sistemlerine göre yanal yüklemeye karşı daha yüksek bir dayanıma sahip olduğu görülmüştür. Ayrıca, kazıklı radye temellerin, hem yatay hem de düşey yüklemelerde kazık gruplarına göre daha yüksek dayanıma sahip olduğu ve eğimli kazık yerleşimi ile deplasmanların da önemli ölçüde azaltılabileceği görülmüştür. Albusoda ve Alsaddi (2017) [10] tabakalı kum zeminde yer alan tekil ve grup kazıkların yanal yük altındaki davranışlarını, kazık yerleşim açıları, kazık sayısı, kazıklar arası mesafe ve kazık konfigürasyonu üzerinden deneysel olarak araştırmışlardır. Sonuçlar, $10^{\circ}$ ve $20^{\circ}$ açı ile yerleştirilen negatif yönlü eğik kazıkların, düşey kazıklara göre yanal taşıma kapasitesinde sırası ile \%32 ve $\% 76$ performans artışı sağladığını ortaya koymuştur. Kazık grupları için, aynı grup içinde düşey ve farklı yerleşim açılarında negatif ve pozitif eğimli kazıkların olduğu bir kombinasyonun kullanılması, nihai yanal taşıma kapasitesinde önemli bir artışa neden olmuştur. Kyung ve 
Lee (2018) [11] tarafından yapılan çalışmada, mikro kazıkların yanal yük taşıma kapasiteleri, sonlu elemanlar yöntemine göre mikro kazık yerleşim açısına bağlı olarak elde edilmiştir. Tekil ve grup mikro kazıklar, farklı yerleşim açılarında, yükleme doğrultularında ve mikro kazıklar arası mesafelerde model deney çalışmaları ile araştırılmıştır. Sonlu elemanlar analizlerinden, eğimli mikro kazıkların yanal yük taşıma kapasitesini belirleyen ana bileşenlerin pasif göçme zonu ve mikro kazık yüzeyinde oluşan sürtünme direnci olduğunu öne sürmüşlerdir. Araştırmacılar, yanal yük etkisindeki tek ve grup mikro kazıklar için bir tasarım yöntemi önermişler ve tam ölçekli saha yükleme test sonuçları ile tasarım yönteminden tahmin edilen sonuçlar arasında iyi bir uyum elde etmişlerdir. Reddy ve Ayothiraman (2015) [12] kum zemin içerisine yerleştirilen tekil kazığın, bağımsız çekme ve yanal yük ile bunların kombinasyonu altındaki davranışını model deneyler ile araştırmışlardır. Sonuçlar yük deplasman davranışının hem bağımsız yüklemeler hem de kombine yükleme durumunda doğrusal olmadığını göstermiştir. Ayrıca, bağımsız yükleme altındaki kazıkların davranışının, kombine yüklemeye kıyasla önemli ölçüde farklı olduğu da gözlemlenmiştir. Kombine yükleme altında nihai taşıma kapasitesi önemli ölçüde artarken, kazık başında meydana gelen sapmanın kombine yükleme durumunda arttığ 1 görülmüştür. $\mathrm{Bu}$ durum, kombine yükleme durumunda artan kapasiteye rağmen, sistemin pratik tasarımda uygulanmasının mümkün olamayacağını göstermiştir. Bu nedenle, tasarımda kullanılan güvenli yanal/çekme yükünün, kombine yüklemenin etkisi göz önüne alındığında, kazıkların sınırlayıcı sapma/yer değiştirme kriterlerini karşılamak için doğrulanması gerektiğini ortaya koymuştur. Bisaws ve ark. (2015) [13] homojen ve tabakalı zemin ortamına yerleştirilen serbest başlı uzun ve kısa kazıklar üzerinde gerçekleştirdikleri model deney çalışmalarını, yanal yatak katsayılarını elde ettikleri sayısal analiz sonuçları ile desteklemişlerdir. Yanal yatak katsayısına geçiş yapabilmek için, Plaxis 3-D foundation programından elde edilen kazık boyunca sapma değerleri, sonlu farklar yöntemi ile analiz edilmiştir. Elde edilen sayısal sonuçların, homojen ve tabakalı kum ortamındaki hem uzun hem de kısa kazıklar için deneysel çalışmalar ile oldukça uyumlu olduğu görülmüştür. Kısa kazıklarda yanal yatak katsayısı, kum sıkılığı ve kazık narinliğinin artması ile artmış, uzun kazıklarda ise kum sıkılığının artması ile artarken, kazık narinliğinin 40 ve üstündeki değerleri için azalmıştır. Hai-Lin ve ark. (2014) [14] kum zemin içerisine yerleştirilen yanal yük altındaki tekil, rijit kısa kazığın zemin-yapı etkileşiminin incelenmesi için ölçüm sistemi destekli deneysel çalışmalar gerçekleştirmişlerdir. Kazık ve kazığı çevreleyen zemin bölgesi, esnek gerinim pulları, dokunsal basınç levha sensörleri ve toprak içi basınç sensörleri gibi gelişmiş ölçüm sistemleri kullanılarak değerlendirilmiştir. Yerleştirilen tüm bu ölçüm sistemleri ile, kazıkzemin arayüz basınçları, kazık boyunca yanal deplasman, kazığın yanal yönde yüklenmesi ile kazı̆̆ı çevreleyen zemin bölgesindeki yanal gerilme değişimlerinin dağılımı, gerçek zamanlı olarak ölçülmüş ve literatürde yer alan diğer yaklaşımlar ile karşılaştırılmıştır. Kwon ve ark. (2014) [15] kum zemin içerisine yerleştirilen kısa kazıkların, yanal çekme yükü altındaki davranışlarını model deney çalışması ile araştırmışlardır. Kazık boyu, çapı ve yükleme noktasının değiştirildiği yanal yükleme deneyleri ile kazığın yanal çekme dayanımı ve dönme hareketi incelenmiştir. Sonuçlar, kazık gömülü uzunluğunun, kazık çapının ve yükün uygulanma noktasının, kum zemine yerleştirilen kısa kazığın yanal çekme dayanımı üzerinde oldukça etkili olduğunu ortaya koymuştur. Manoppo (2009) [16] homojen kum zemin içerisine yerleştirilen yanal yüklü uzun ve eğik kazığın nihai taşıma gücü değerlerini, deneysel ve analitik olarak araştırmıştır. Kazıklar gevşek, orta sıkı ve sıkı zemin koşullarında, $0^{\circ},+15^{\circ},+30^{\circ},-15^{\circ}$ ve $-30^{\circ}$ 'lik açılarda yerleştirilmiştir. Deneysel çalışmalar sonucunda, eğim açısı ve zeminin birim hacim ağırlığının önemli etkisi olduğu ortaya çıkmıştır. Negatif 
açıda yerleştirilen kazığın taşıma kapasitesi, düşey ve pozitif açıda yerleştirilen kazıklardan daha büyük çıkmıştır. -15 derecede yerleştirilen kazığın taşıma kapasitesi, düşey kazığın yanal yük taşıma kapasitesinin 1.25 katı olarak elde edilmiştir. Zhang ve ark. (1999) [17] santrifüj deneyleri ile kazık yerleşim açılarının uzun kazığın yanal yük taşıma kapasitesine olan etkilerini rölatif sıkılık değeri \%55 olan orta sıkı ve \%36 olan gevşek zemin koşullarında incelemişlerdir. Santrifüj deneylerinde, düşey kazık yerleşimine ilave olarak, yükleme doğrultusu ve yüklemeye zıt doğrultuda yerleştirilmiş $7^{\circ}$ ve $14^{\circ}$ yerleşim açıları kullanılmıştır. Elde edilen deneysel sonuçlar, kazık açısı ve eğik durumda elde edilen yanal zemin dayanımının, düşey durumda elde edilen yanal zemin dayanımına oranı cinsinden hazırlanmış eğriler üzerinden yorumlanmıştır. Elde edilen sonuçlar literatür ile karşılaştırılmış ve tutarlı olduğu görülmüştür.

$\mathrm{Bu}$ çalışmada, yanal yük etkisindeki düşey $\left(0^{\circ}\right)$ ve eğik $\left(+20^{\circ},+10^{\circ},-10^{\circ}\right.$ ve $\left.-20^{\circ}\right)$ rijit kazıkların, homojen sıkı kum zemin ve kazık gömülü boyunun \%30, 60, 90 ve 100'ünün gevşek kum zeminin içinde kaldığı tabakalı zemin koşullarında, taşıma kapasitelerinin belirlenmesi hedeflenmiştir. Bu amaçla, laboratuvar ortamında küçük ölçekli model deneyler yapılmış ve elde edilen sonuçlar, sonlu elemanlar yöntemi ile non-lineer analiz yapan [1819] PLAXIS program çıktıları ile hem 2 hem de 3 boyutlu olarak karşılaştırılmıştır. 3 boyutlu analizler, küçük ölçekli model deney çalışmalarına bağlı kalınarak, deney koşullarının, model geometrisi, yükleme koşulları, sınır şartları ve malzeme parametreleri dikkate alınarak modellenmesi ile gerçekleştirilmiştir. 2 boyutlu analizler ise alternatif bir çözüm önerisinden ziyade, 3 boyutlu sayısal bir çözümün imkanlar dahilinde olmadığı bir durumda, kısa kazığın yanal yük taşıma kapasitesinin tahmininde ön çalışma olarak irdelenmiştir. Bu amaçla; deney sonuçları ile 2 boyutlu düzlem deformasyon koşullar kullanılarak elde edilen sayısal analiz sonuçları arasında karşılaştırma yapılabilmesi için, 2 boyutlu analiz sonuçları uygun birer katsayı ile çarpılarak, geometrik dönüşüm sebebi ile oluşan mertebe farkı giderilmiştir. Katsayılar, zemin koşulları ve kazık yerleşim açılarına bağlı olarak elde edilmiştir. Bu katsayıların elde edilmesinde kullanılmayan, homojen sıkı kum zemin içerisine $+15^{\circ}$ ve $15^{\circ}$ 'lik açılarda yerleştirilen kazığa ait iki farklı yük-deplasman davranışı üzerinden, katsayı seçiminin uygunluğu kontrol edilmiştir.

\section{DENEYSEL ÇALIŞMALAR}

Bir kazığın yanal yük altındaki göçme mekanizması, kazığın kısa (rijit) veya uzun (flexible) oluşuna göre farklılık göstermektedir. Kazığın uzun veya kısa oluşu, boy-çap ve kazık zemin arasındaki rijitlik ilişkisi ile açıklanmaktadır. Kısa kazıklar, narin yapılı uzun flexible kazıkların aksine, çapları veya genişlikleri büyük ancak, uzunlukları küçük olan, oldukça rijit yapısal elemanlardır. Flexible (uzun) kazıklarda, yanal yük etkisi altında kazıkta meydana gelen ötelenmeler sonucu kazık kesit alanının yenilme momentinin aşılması ile göçme meydana gelirken, rijit kısa kazıklarda göçme, kazığın yanal yük etkisi altında bir nokta etrafında dönerek zemine yaslanması ve zeminin taşıma gücünün aşılması ile meydana gelmektedir.

Broms (1964b) [4] tarafından düşey kazıkların yanal yük altındaki dayanımları için önerilen analitik çözüm yöntemi, kazıkların uzun veya kısa oluşlarına göre detaylandırılmıştır. Kohezyonsuz zeminlere yerleştirilen kazıklarda $\mathrm{L} / \mathrm{T}<2$ ise kısa kazık, $\mathrm{L} / \mathrm{T}>4$ ise kazık, uzun kazık davranışı sergilemektedir (Broms (1964b) [4], Chari ve Meyerhof (1983) [20]). 
Burada; L kazığın gömülü uzunluğu, T ise, Matlock ve Reese (1960) [21] tarafından önerilen rijitlik faktörü olarak tanımlanmıştır (Denklem 1).

$$
T=\left(\frac{E_{k} I_{k}}{\eta_{h}}\right)^{\frac{1}{5}}
$$

Karatzia ve Mylonakis (2012) [22] lineer regresyon analizinden elde ettikleri matemetiksel yaklaşıma göre, kazığın boy çap oranı ile, etkileşim halinde olan kazık ve zeminin rijitlikleri arasında Denklem (2)'deki bağıntının olduğunu öne sürmüşlerdir.

$$
\frac{L}{D}>\left(\frac{E_{k a z i k}}{E_{z e \min }}\right)^{0.25}
$$

Tomlinson (2001) [23] kazığg, gömülü boyu ile çapının oranının (L/D) 10-12'den düşük olduğu değerleri için "Kısa Kazık" olarak tariflemiştir. Santana ve ark. (2018) [24] zemin içine gömülü herhangi bir yapının rijit veya esnek bir davranış sergilemesinde, gömülü elemanın narinlik oranı (L/D) ile zemin ve yapı rijitliğinin etkisinin olduğunu ifade etmişler, narinlik oranının 6'dan küçük olduğu $(\mathrm{L} / \mathrm{D}<6)$ gömülü elemanlarda davranışın yapı-zemin rijitliğinden bağımsız şekilde, rijit olarak ele alınması gerektiğini vurgulamışlardır. Giannakou ve ark. (2006) [25] ise L/D değerinin 7.5'tan küçük olduğu kazıkların Ep/Es oranından bağımsız olarak "Rijit Kazık" olarak tarfilenebileceğini öne sürmüşlerdir. Badry ve Satyam (2018) [26] yanal yük altındaki kazık davranışının boy çap ilişkisi dikkate alındığında kazıkların kısa ve uzun olarak 2 farklı kategoride değerlendirilerek L/D oranının 30'dan büyük olduğu kazıkların uzun, 20'den küçük olduğu kazıkların ise kısa kazık olarak tariflendiğini ifade etmişlerdir. Dolayısıyla, yukarıda sıralanan referanslar göz önünde bulundurulduğunda, bu çalışmada kullanılan $\mathrm{L} / \mathrm{D}=4$ oranına sahip çelik kazığın kısa kazık olarak tariflenmesi gerektiği açıktır.

Deneyler, Çukurova Üniversitesi, İnşaat Mühendisliği Bölümü, Geoteknik Laboratuvarında gerçekleştirilmiştir. Küçük ölçekli model deneyler ile rijit (kısa) kazığın homojen sıkı ve/veya tabakalı kum zemin ortamına düşey ve/veya eğik yönlü yerleştirilmeleri durumları araştırılmıştır. Deneylerde, homojen sıkı ve 4 farklı tabakalı kum zemin koşulları için kazığın zemin içerisinde düşey, yük doğrultusu yönünde ve yük doğrultusuna zit yönde yerleştirilmesi durumları dikkate alınmıştır.

\subsection{Deney Kasası ve Yükleme Düzeneği}

Deneylerde kullanılan kasa, 50 cm yüksekliğinde, $48 \mathrm{~cm}$ genişlik ve $96 \mathrm{~cm}$ uzunluğundadır. Kasanın dar kenarlarını ve tabanını oluşturan yüzeyler $2 \mathrm{~cm}$ kalınlıkta ahşap malzemeden, uzun kenar doğrultusundaki iki yüzeyi ise $1 \mathrm{~cm}$ kalınlıktaki cam malzemeden oluşmaktadır. Kasanın iskeleti ise $5 \mathrm{~mm}$ kalınlıktaki çelik profillerden imal edilmiştir (Uncuoğlu, 2015) [27]. Kasa boyutları, sınır etkisi oluşmayacak şekilde sayısal analiz sonuçları dikkate alınarak hazırlanmıştır. Çalışmalar sırasında, kum zemini kasa içerisine rahat yerleştirebilmek ve 
uygun zemin sıkılıklarını sağlayabilmek için, kasa iç yüzeyleri 3'er cm aralıklarla çizilerek, kum zeminin tabakalı yerleşimine olanak sağlayacak şekilde hazırlanmıştır. Deney kasası ve yükleme sistemine ait şematik görünüm Şekil 1'de verilmiştir.
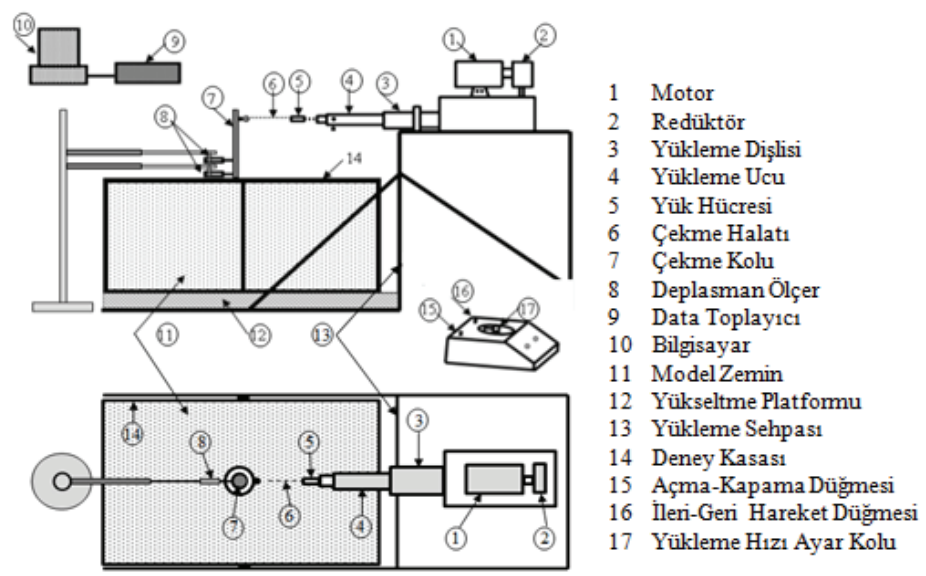

Şekil 1 - Deney Kasası ve Yükleme Düzeneği Şematik Gösterimi (Mısır, 2015) [28]

\subsection{Malzeme Parametreleri}

Deneysel çalışmalarda çelik malzemeden imal edilen model kısa kazık ve çekme kolu kullanılmıştır. Deneyler, kısa kazığa sabitlenmiş çekme koluna uygulanan yanal yük ile gerçekleştirilmiştir. Model kazık ve çekme koluna ait çap $\left(D_{\text {kazk }}, D_{\text {çekme kolu }}\right)$, uzunluk (L, $\mathrm{L}_{\text {cekme kolu }}$, birim hacim ağırlık $(\gamma)$, elastisite modülü $(\mathrm{E})$ ve poisson oranı $(v)$ bilgileri Tablo 1'de verilmiştir.

Tablo 1 - Kazık ve Çekme Koluna ait Parametreler

\begin{tabular}{|c|c|c|}
\hline & Model Kazık & Çekme Kolu \\
\hline Malzeme Cinsi & Çelik & Çelik \\
\hline Çap (mm) & 50 & 25 \\
\hline Boy (mm) & 200 & 300 \\
\hline Elastisite Modülü (MPa) & 210000 & 210000 \\
\hline Birim Hacim Ăğırlık (kN/m³) & 77 & 77 \\
\hline Poisson Oranı & 0.25 & 0.25 \\
\hline
\end{tabular}

Yanal yük etkisindeki kısa kazıkların davranışının deneysel olarak araştırılması amacıyla, yanal yükün uygulanma yüksekliği, Karayolları Genel Müdürlüğü'nün, ilgili yönetmeliğinde [29] öngörülen yükseklik değerleri $(6 \mathrm{~m})$ ile uyumlu olması için düzenek, 1/20 ölçekte hazırlanmıştır. Laboratuar ortamında gerçekleştirilen model deney çalışmaları için Çukurova 
Bölgesi, Çakıt Deresi yatağından getirilen kum malzeme kullanılmıştır. Dane çapı dağılımına ait granülometri eğrisinden zemin sınıfı, Birleştirilmiş Zemin Sınıflandırma Sistemine göre, kötü derecelenmiş kum, SP olarak elde dilmiştir. Dane birim hacim ağrılı̆̆ $26.8 \mathrm{kN} / \mathrm{m}^{3}$ olan kum zemin iki farklı zemin sıkılığında hazırlanmış olup, kuru birim hacim ağırlıkları gevşek ve sıkı kum zemin durumları için sırasıyla $15.03 \mathrm{kN} / \mathrm{m}^{3}$ ve $17.06 \mathrm{kN} / \mathrm{m}^{3}$ olarak elde edilmiştir. Kesme kutusu ve üç eksenli basınç deneyi sonucuna göre, içsel sürtünme açıları ise sırasıyla; gevşek kum zemin için $39^{\circ}-38^{\circ}$ ve sıkı kum zemin için ise $46^{\circ}-44^{\circ}$ olarak elde edilmiştir (Şekil 2-3).

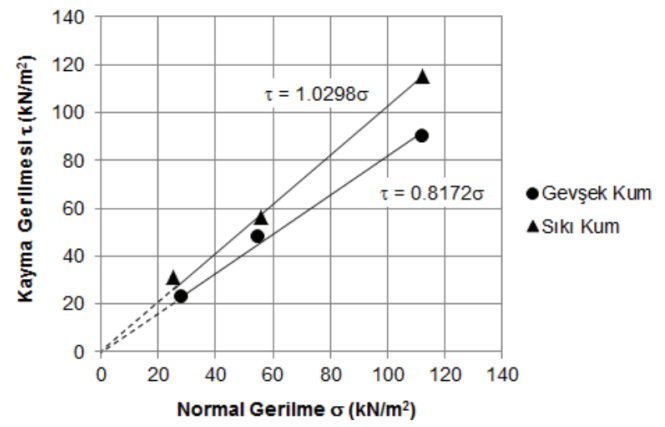

Şekil 2 - Gevşek ve Sıkı Kum Zemine ait Kesme Kutusu Deney Sonuçları
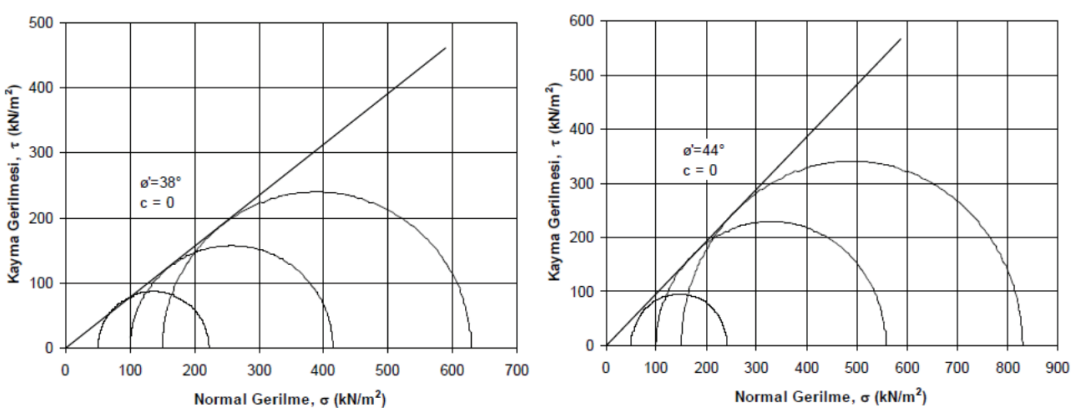

Şekil 3 - Gevşek ve Sıkı Kum Zemine ait Üç Eksenli Basınç Deney Sonuçları

\subsection{Deney Prosedürü}

Kum zemin, hem gevşek hem de sıkı durumda, iç yüzeyleri $3 \mathrm{~cm}$ aralıklı yatay çizgiler ile bölünerek ölçeklendirilmiş deney kasası içerisine her bir tabaka için gerekli olan kum ağırlığı hesaplanıp tartılarak yerleştirilmiştir. Gevşek kum zemin tabakaları için hesaplanan malzeme miktarı, kasa içerisine dökülürken herhangi bir sıkışmaya meydan vermeyecek şekilde kasa içerisine mümkün olan en yakın mesafeden dökülmüş ve her tabakadaki zemin yüzeyi zemine baskı yapılmaksızın düzeltilmiştir. Sıkı kum zemin durumunda ise, her tabakaya girecek malzeme miktarı gevşek kum zemin tabakasında olduğu gibi kasa içerisine yerleştirilmiş, hazırlık deneyleri aşamasında belirlenmiş olan miktarda enerji, titreşim cihazı ile kontrollü bir şekilde uygulanmış ve konulan kum zeminin gerekli tabaka yüksekliği seviyesine gelmesi 
sağlanmıştır. Hem gevşek hem de sıkı kum zemin durumunda yerleştirilen her bir tabakanın kalınlığı, cam yüzeyler üzerinde bulunan ve tabaka sınırlarını belirleyen yatay çizgilere göre kontrol edilmiştir. Kazık ucunun oturacağı zemin yüzeyi seviyesine ulaşılıncaya kadar kum zemin, kasa içerisine belirtilen yol izlenerek doldurulmuştur. Bu seviyeye gelindiğinde, zemin yüzeyinin düzgünlüğü kasanın uzun ve kısa kenarı doğrultusunda, su terazisi kullanılarak kontrol edilmiştir. Model deneylerde kazığın, zemin içerisinde uygun açılarda yerleştirilebilmesi ve kasa kum zemin ile tamamen doluncaya kadar, gerek gevşek zemin tabakaları, gerekse sıkıştırma işleminin uygulandığı zemin tabakalarında, titreşim cihazının deney düzeneğine vereceği etkiyi en aza indirmek ve kazığı kasa içerisinde sabit konumda tutabilmek için kazık sabitleme aparatı kullanılmıştır (Şekil 4a-4b).
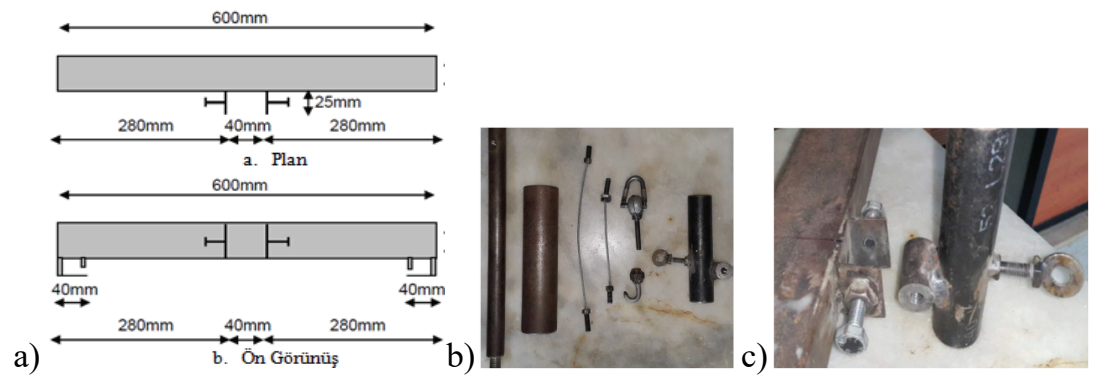

Şekil 4 - a) Kazık Sabitleme Aparatı [9], b) Gömülü Kazık Eleman, Çekme Kolu ve Bağlantı Aparatları [28], c) Kazık Döndürme Aparatının Sabitlenmesi (Mısır, 2015) [28]

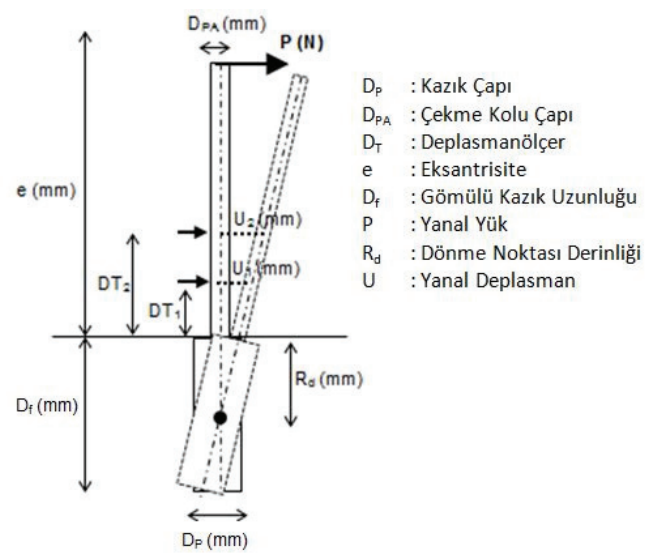

Şekil 5 - Model Deney Sistemine ait Geometri (Misır, 2015) [28]

Kazık döndürme aparatı ise, kazık sabitleme aparatına yerleştirilen birbirine kaynakla monte edilmiş, iki ayrı dairesel çelik borudan oluşmaktadır (Şekil 4c). Yatay olan parça, kazık sabitleme aparatına monte edilen kısım olup, iç çapı bağlantı elemanı olan vidanın girebileceği kadardır. Düşey konumda olan çelik boru ise, çekme koluna bağlanıp, istenilen açıda kazığı sabitlemek için kullanılmıştır. Açı değeri, açıölçer yardımıyla belirlenip, sabitlenmiştir. 
Gömülü kısa kazık eleman yanal yük etkisi altında Şekil 5'te verildiği gibi, kısa kazık üzerinde oluşan bir dönme noktası etrafında rijit bir dönme hareketi yapacaktır. Bu hareket ile, kazık çekme kolu üzerinde alınacak 2 noktanın yatay deplasmanından yola çıkılarak, dönme noktasının yeri belirlenebilmektedir. Bu amaçla; zemin yüzeyinden 14 ve $23 \mathrm{~cm}$ mesafede, kazık çekme kolu üzerine 2 adet deplasmanölçer yerleştirilmiştir. Yüklemelere üstteki deplasman ölçerin $1 \mathrm{~cm}$ 'lik kapasitesine ulaşılıncaya kadar devam edilmiştir. Yanal yük ise, zemin yüzeyi üzerinden $300 \mathrm{~mm}$ yükseklikte, çekme koluna vidalanmış bilyalı bir kancaya bağlanan çelik halat yardımı ile uygulanmış ve uygulanan yük değerleri $500 \mathrm{~N}$ kapasiteli yük halkası ile ölçülmüştür.

\subsection{Deney Programı}

Deneysel çalışmalarda, rijit (kısa) kazığın homojen sıkı ve tabakalı kum zemin içerisine, düşey ve/veya eğik olarak yerleştirilmesi durumlarında elde edilen taşıma kapasiteleri 27 farklı model deney sonucu ile değerlendirilmiştir. Deney programı hazırlanırken, homojen sıkı kum zemin koşulu için $-20^{\circ},-15^{\circ},-10^{\circ}, 0^{\circ},+10^{\circ},+15^{\circ}$ ve $+20^{\circ}$ 'lik kazık yerleşim açılarına sahip kısa kazıkların davranışları incelenmiştir (Tablo 2a). Tabakalı zemin koşullarında ise, gevşek zemine ait tabaka kalınlıkları 6, 12, 18 ve toplam kazık boyu olan $20 \mathrm{~cm}$ arasında değişen 4 farklı tabakalı kum zemin durumu dikkate alınmıştır. Tabakalı zemin koşullarında kazık yerleşim açıları $-20^{\circ},-10^{\circ}, 0^{\circ},+10^{\circ}$ ve $+20^{\circ}$ arasında değiştirilmiştir (Tablo 2b).

Tablo $2 a$ - Homojen Zemin Koşulunda Deney Programı

\begin{tabular}{cc}
\hline KAZIĞIN YERLEŞİM ŞEKLI & SIKI KUM \\
\hline Yükleme Yönünde Yerleştirilmiş Kazık & $\mathrm{D}-\mathrm{S}(-20)$ \\
(Negatif Yön) & $\mathrm{D}-\mathrm{S}(-15)$ \\
$\mathrm{D}-\mathrm{S}(-10)$ \\
\hline Düşey Yerleşimli Kazık & $\mathrm{D}-\mathrm{S}(0)$ \\
\hline Yüklemeye Zit Yönde Yerleştirilmiş Kazık & $\mathrm{D}-\mathrm{S}(10)$ \\
(Pozitif Yön) & $\mathrm{D}-\mathrm{S}(15)$ \\
& $\mathrm{D}-\mathrm{S}(20)$ \\
\hline
\end{tabular}

Tablo 2 - Tabakalı Zemin Koşulunda Deney Programı

\begin{tabular}{ccccc}
\hline $\begin{array}{c}\text { Gevşek } \\
\text { Tabaka }\end{array}$ & $\begin{array}{c}\text { 6 cm }(\% 30) \\
\text { GEVŞEK } \\
\text { Kalınığı }\end{array}$ & $\begin{array}{c}\text { 12 cm }(\% 60) \\
\text { KEVŞEK }\end{array}$ & $\begin{array}{c}\text { 18 cm }(\% 90) \\
\text { GEVŞEK } \\
\text { KUM }\end{array}$ & $\begin{array}{c}\text { 20 cm }(\% 100) \\
\text { GEVŞEK } \\
\text { KUM }\end{array}$ \\
\hline & D-T6(-20) & D-T12(-20) & D-T18(-20) & D-T20(-20) \\
& D-T6(-10) & D-T12(-10) & D-T18(-10) & D-T20(-10) \\
Deney Adı & D-T6(0) & D-T12(0) & D-T18(0) & D-T20(0) \\
& D-T6(10) & D-T12(10) & D-T18 $(10)$ & D-T20(10) \\
& D-T6(20) & D-T12(20) & D-T18 $(20)$ & D-T20(20) \\
\hline
\end{tabular}


Burada $\mathrm{D}$, deneysel çalışmadan elde edilmiş olması durumunu, $\mathrm{S}$, homojen sıkı zemin koşulunu, T ise zemin yüzeyinden $6,12,18$ ve $20 \mathrm{~cm}$ (kazık boyunun sırasıyla \%30, 60, 90 ve 100 'ünün gevşek kum zemin içinde olması) derinliklerde değişen gevşek tabaka kalınlıklarını gösteren tabakalı kum zemin koşulunu sembolize etmektedir. Parantez içinde yer alan değerler ise, kazığın düşey eksene göre yerleşim açısını göstermektedir.

\section{3 BOYUTLU (3D) ve 2 BOYUTLU (2D) SAYISAL ANALIZLER}

Temel mühendisliği problemlerinin sonlu elemanlar, sonlu farklar vb. sayısal analiz yöntemleri ile hesaplanması son yıllarda yaygın olarak kullanılmaktadır. Bu tarz yöntemler, mevcut hesap yöntemlerine alternatif olarak geliştirilmiş ve hesap kolaylığı, zaman tasarrufu, geliştirilen kullanıcı dostu ara yüz programları ve alternatif çözümlerin kolayca denenebildiği parametrik çalışmalara olanak tanıması nedeni ile kullanımı giderek yaygınlaşmaktadır. Yanal yüklü eğik kazıkların sayısal modellemeleri ile ilgili birkaç çalışmaya aşağıda yer verilmiştir.

Rajashree ve Sitharam (2001) [30] tarafından yapılan çalışmada yanal yüklü eğik kazıkların statik ve tekrarlı yükler altındaki davranışını modellemek için, kazığın bir kiriş eleman, zeminin ise, elastoplastik yay elemanlar olarak modellendiği bir sonlu elemanlar programı geliştirilmiştir. Statik durum için zemin davranışı hiperbolik modelle, tekrarlı yükler altındaki zemin davranışı ise modifiye hiperbolik modelle oluşturulmuştur. Geliştirilen model, statik ve tekrarlı yükler altında yapılmış olan laboratuvar ve arazi deney verileri ile doğrulanmıştır. Yang ve Jeremic (2005) [31] tarafından plastik-plastik zemin içerisindeki tekil kazığın davranışı, 3 boyutlu OpenSees programı ile incelenmiştir. Kazık davranışı, kazığın üniform kum zemin, üniform kil zemin, kil içerisinde kum tabakası ve kum zemin içerisinde kil tabakasına yerleştirilmesi durumları için analiz edilmiş ve sonuçlar p-y eğrileri ile karşılaştırılmıştır. Karthigeyan ve ark. (2007) [32] homojen kum ve kil zemin içerisindeki kazığa etkiyen düşey yükün, kazığın yanal yük taşıma kapasitesine olan etkilerini GEOFEM3D programı ile araştırmışlardır. Kil zemin için Von-Mises göçme kriteri, kum zemin için Drucker-Prager malzeme modeli kullanılmıştır. Kumlu ve killi zeminlerde gerçekleştirdikleri analiz sonuçlarını, literatürdeki deneysel çalışmalar ile doğrulamışlardır. Kumlu zeminde yapılan analizlerde düşey yükün artması, yanal yük taşıma kapasitesini \%40'a kadar arttırmaktadır. Kombine yük altındaki kazıkların yanal yük taşıma kapasiteleri, aynı zamanda, L/B oranına da bağlı olup, bu oranın artması ile düşey yükün yanal kapasite üzerinde yarattığı etki azalmaktadır. Kum zeminlerde, L/B oranının 25 'ten, kil zeminlerde ise 16'dan büyük olduğu durumlarda, düşey yüklemenin, kazığın yanal yük taşıma kapasitesi üzerindeki etkisi sabit kalmaktadır. Achmus ve ark. (2009) [33] tarafindan kisa ve uzun kazıkların eğik yükler altındaki davranışları ABAQUS 3D programı ile analiz edilmiştir. Kazıklar üzerine, yatay ile $0^{\circ},+30^{\circ},+60^{\circ}$ ve $+90^{\circ}$ açı yapacak şekilde eğik yükler uygulanmıştır. Sayısal modellemede kullanılacak nihai yük değeri ise, kazık başının $20 \mathrm{~cm}$ (kazık çapının \%10’u) deformasyonuna karşılık gelen değerler olarak alınmıştır. Kombine yük altında kazık-zemin etkileşimi uzun ve kısa kazıklar için bir diyagramda özetlenmiştir. Basınca zorlanan eğik yük altındaki rijit ve flexible kazıkta meydana gelen yatay deplasman, eğim açısından, dolayısı ile düşey yükten bağımsızken, rijit kazıkta yatay yük bileşeninin düşey deplasman değeri üzerinde oldukça etkili olduğu görülmüştür. Maouche ve ark. (2009) [34] tarafından yanal yüklü kazıkların davranışını modellemek için, Plaxis 2D programı kullanılmıştır. Çalışmanın temel amacı, kazıkta oluşan maksimum yanal ötelenmenin, kazık 
geometrisine ve non-lineerlik etkilerine bağlı olarak incelenmesidir. Bu çerçevede lineer ve non-lineer olarak kabul edilen kumlu ve killi zeminler üzerinde analizler yapılmış ve sonuçlar karşılaştırılan literatürdeki çalışmalar ile oldukça uyumlu çıkmıştır. Rahimi ve Bargi (2010) [7] tarafından yapılan çalışmada, sıkı kum içerisinde yer alan, 21 adet düşey ve 4 adet eğik kazıktan oluşan rıhtım temellerinin davranışını incelemek için, 3 boyutlu ABAQUS programı kullanılmıştır. Eğik kazık pozisyonunu ve eğiminin etkisini araştırmak için yapılan sayısal analizler, kazık başına uygulanan 15.000 kN'luk yatay yük altında gerçekleştirilmiştir. Analizler sonucunda, tüm kazıkların düşey olduğu konfigürasyon içerisinde, yüke en yakın sırada yer alan kazıkların uygulanan toplam yükün, \%33'ünü taşıdığı görülmüştür. Kazıkların eğik yerleşiminin yaratacağı etkiyi incelemek için, $15^{\circ}, 20^{\circ}, 25^{\circ}$ ve $30^{\circ}$ lik kazık açılarında analizler yapılmış ve kazık yerleşim açısının artmasıyla, kazık başında meydana gelen deformasyonlar azalırken, eğik kazıklar tarafından taşınan yük değerleri de belirgin bir şekilde artmıştır. Sawant ve Shukla (2012) [35] tarafından kullanıcı tanımlı sonlu elemanlar yöntemine dayanan üç boyutlu sayısal bir formülasyon geliştirilmiştir. Analizler ile, şev tepesinde ve şev tepesine değişken mesafelerde yerleştirilmiş kazıkların davranışları incelenmiştir. Sonuç olarak, kazığın şev tepesine yerleştirilmesi ile, şev eğiminin 1/2 den 1/1 e yükselmesi durumunda, kazık başındaki deplasmanda \%14'e, eğilme momentinde ise, \%7'ye varan artışlar gözlenmiştir. Şev tepesine olan mesafenin 5D olduğu durumda şev etkisinin azaldığı ve bu mesafede yanal deplasmandaki maksimum artışın, sadece \% 2 kadar olduğu görülmüş̧ür. Mroueh ve Shahrour (2008) [36] tarafindan kombine çekme yüküne maruz eğimli bir kazığın taşıma kapasitesi üç boyutlu sonlu eleman analizleri ile araştırılmıştır. Kazık-zemin ara yüzeyindeki temas şartlarının kazığın tepkisine olan etkisi de incelenmiştir. Sonuçta; uygulanan kombine çekme yükünün, kazık düşey ekseni ile yapmış olduğu açının eğimli kazığın yanal ve düşey yük taşıma kapasitesini etkilediği görülmüştür. Düşey kazıkların yanal yük taşıma kapasitesi kombine yüklemenin eğiminden etkilenmese de aynı sonuç eğimli kazık durumunda gözlenmemiştir. Kazığın yerleşim açısı, kazık çekme kapasitesini arttırmaktadır. Uygulanan kombine çekme kuvvetinin eğimli kazığın düşey ekseni ile yapmış olduğu açı $0^{\circ}$ den $10^{\circ}$ ye kadar artmasılyla çekme kuvveti taşıma kapasitesi de yaklaşık olarak \%50 azalmaktadır. Uygulanan kombine çekme kuvvetinin kazık ekseni ile yapmış olduğu açı $10^{\circ}$ 'yi aştığında, kazık-zemin ara yüzeyindeki etkileşimin etkisi de ihmal edilebilir mertebede elde edilmiştir.

$\mathrm{Bu}$ çalışma kapsamında gerçekleştirilen sayısal analizler, sonlu elemanlar yöntemini kullanan PLAXIS programı yardımı ile gerçekleştirilmiştir. $\mathrm{Bu}$ program, geoteknik problemlerinin deformasyon analizlerinin gerçekleştirilmesi için geliştirilmiş bir programdır. Plaxis programı, hem uygulamacılar hem de araştırmacılar için, 2-D ve 3-D versiyonları ile piyasaya sürülmüştür. Üç boyutlu programda problem, yükleme koşulları, malzeme özellikleri ve sınır şartları bakımından olduğu gibi ele alınıp, modellenebilmektedir. İki boyutlu versiyonunda ise, seçilen problem, problem geometrisi ve yükleme koşuluna uygun olarak, eksenel simetri veya düzlem deformasyon koşullarına indirgenmek durumundadır. $\mathrm{Bu}$ noktada önemli olan, problem geometrisi ve yükleme koşullarının aynı anda sağlanabilmesidir.

Yanal yüklü rijit kazıkların, homojen sıkı ve tabakalı kum zemin içerisine düşey ve eğik olarak yerleştirilmeleri durumundaki yük- deplasman davranışlarının incelenmesi amacıyla, Plaxis 2D v.8.2 ve Plaxis 3D 2013 programları kullanılmıştır. Problemin, üç boyutlu olarak ele alınarak deney sonuçları ile karşılaştırılması en uygun analitik çözüm yöntemidir. 
Sistemin iki boyuta indirgenmesi ise bir fizibilite çalışması olarak kabul edilmiş ve sonuçlar bir katsayı yaklaşımı ile gerçek davranışa dönüştürülmüştür.

\subsection{Plaxis 3D ile Yapılan Analizler}

Homojen sıkı ve tabakalı kum zemin koşullarında, kazık yerleşim açısının, kazığın yanal yük taşıma kapasitesine etkisini araştırmak için, üç boyutlu sonlu elemanlar yöntemi ile analizler yapılmıştır. Model geometrisi ve sınır şartları, deney kasası dikkate alınarak oluşturulmuştur. Sayısal analizlerde, hem sıkı hem de gevşek kum zemin için Mohr-Coulomb malzeme modeli kullanılmıştır. Bu modelde kullanılan elastisite modülü değeri, iki farklı sıkılıktaki kum zemin için üç eksenli deney sonuçlarından elde edilmiştir. Modelde, elastiste modülünün derinlikle lineer olarak değişen bir yaklaşımla tanımlanması, sabit elastisite modülü kullanılarak elde edilen yük-deplasman davranışına göre daha gerçekçi sonuçlar ortaya koymuştur. Homojen gevşek ve T20 setine ait tabakalı kum zemin durumu için artımsal ve referans eleastisite modüllerinin temsili hesap detayları Mısır 2015'te [28] verilmiştir. Plaxis analizlerinde, derinlikle değişen rijitlik yaklaşımının kullanılabilmesi için, herhangi bir referans derinliğinde $\left(\mathrm{y}_{\mathrm{ref}}\right)$ başlangıç elastisite modülü $\left(\mathrm{E}_{\mathrm{ref}}\right)$ ve artan her birim derinlik için artımsal elastisite modülünün $\left(\mathrm{E}_{\text {inc }}\right)$ tanımlanması gerekmektedir. Tabakalı kum zemin durumunda, derinlikle lineer olarak değişen elastisite modülleri tanımlanırken, hem değişken kalınlıktaki gevşek kum, hem de bu tabakayı takip eden sıkı kum zemin tabakası için parametreler hesaplanmıştır. Analizlerde kullanılan homojen sıkı kum ve tabakalı durumda üstteki gevşek kum zemin tabakalarına ait malzeme parametreleri Tablo 3 'te verilmiştir.

Tablo 3 - Gevşek ve Sıkı Kum Zemin için Zemin Parametreleri

\begin{tabular}{|c|c|c|}
\hline & Gevşek Kum & Sıkı Kum \\
\hline$\gamma_{\mathrm{n}}\left(\mathrm{N} / \mathrm{cm}^{3}\right)$ & 0.015 & 0.017 \\
\hline$E_{\text {ref }}\left(M N / m^{2}\right)$ & 0.01 & 0.01 \\
\hline$E_{\text {inc }}\left(\mathbf{M N} / \mathbf{m}^{2} / \mathbf{c m}\right)$ & 0.624 & 1.020 \\
\hline $\mathbf{y}_{\text {ref }}(\mathbf{c m})$ & 0 & 0 \\
\hline$c\left(k N / m^{2}\right)$ & 0.01 & 0.01 \\
\hline$\varphi\left({ }^{\circ}\right)$ & 38 & 44 \\
\hline$\psi\left({ }^{0}\right)$ & 8 & 14 \\
\hline
\end{tabular}

Gevşek kum tabakasını takip eden sıkı kum zemin için ise, referans derinliği ( $\left.\mathrm{y}_{\text {ref }}\right)$ değişken olup, ilgili derinlikteki referans elastisite modülü ve dolayısı ile artımsal elastisite modülü değerleri ayrı ayrı hesaplanmalıdır. Karşılaşatırmalarda kullanılan tipik set (T20) için elastisite modülü değerleri Tablo 4'te verilmiştir.

Üç boyutlu sayısal analizlerde, yanal yük altındaki rijit kazık ve çekme kolunu modellemek için, kiriş (beam) eleman kullanılmıştır. Analizlerde kullanılan çelik kazık ve çekme kolu için kiriş elemana tanımlanan malzeme parametreleri Tablo 5 'te verilmiştir. Modelin analiz adımları tanımlanırken, ilk analiz adımı olarak başlangıç gerilme durumunun tanımlanması gerekmektedir. Başlangıç gerilme durumu Plaxis programında, "K0 Procedure” ya da 
"Gravity Loading” seçeneklerinden uygun olanı kullanılarak tanımlanmaktadır. "K0 Procedure", yüklemeler ve yapısal nesneler hariç, sadece zeminin ağırlığını ve boşluk suyu basınçlarını dikkate almaktadır. Ayrıca bu seçenek deneysel çalışmalarda olduğu gibi, sadece zemin yüzeyinin yatay olduğu ve bütün zemin tabakaları ile yer altı su seviyesinin bu zemin yüzeyine paralel olduğu durumlarda kullanılmaktadır. Analizler, başlangıç gerilme durumunun tanımlanmasının ardından zemin üst kotundan $30 \mathrm{~cm}$ yukarıda uygulanan yanal hareket ile deplasman kontrollü olarak gerçekleştirilmiştir. 3 boyutlu sonlu elemanlar modeli ve ağ düzenine ait tipik bir görüntü Şekil $6 a$ ve b'de verilmiştir.

Tablo 4 - 20 cm Gevşek Kum Zemin Kalınlı̆̆ında Elastisite Modülü Değerleri

\begin{tabular}{clc}
\hline DENEY KOŞULLARI & Elastisite Modülü & Tabakalı Kum Zemin T20 \\
\hline \multirow{2}{*}{ Gevşek Kum Tabakası } & $\mathrm{E}_{\text {ref }}\left(\mathrm{MN} / \mathrm{m}^{2}\right)$ & 0.01 \\
& $\mathrm{E}_{\text {inc }}\left(\mathrm{MN} / \mathrm{m}^{2} / \mathrm{cm}\right)$ & 0.624 \\
\hline \multirow{2}{*}{ Sıkı Kum Tabakası } & $\mathrm{E}_{\text {ref }}\left(\mathrm{MN} / \mathrm{m}^{2}\right)$ & 12.490 \\
& $\mathrm{E}_{\text {inc }}\left(\mathrm{MN} / \mathrm{m}^{2} / \mathrm{cm}\right)$ & 1.497 \\
\hline \multirow{2}{*}{ Sıkı Kum 10 $\mathbf{1 0}$ ğimli Kazık } & $\mathrm{E}_{\text {ref }}\left(\mathrm{MN} / \mathrm{m}^{2}\right)$ & 12.303 \\
& $\mathrm{E}_{\text {inc }}\left(\mathrm{MN} / \mathrm{m}^{2} / \mathrm{cm}\right)$ & 1.481 \\
\hline \multirow{2}{*}{ Sıkı Kum 20 Ĕgimli Kazık } & $\mathrm{E}_{\text {ref }}\left(\mathrm{MN} / \mathrm{m}^{2}\right)$ & 11.741 \\
& $\mathrm{E}_{\text {inc }}\left(\mathrm{MN} / \mathrm{m}^{2} / \mathrm{cm}\right)$ & 1.438 \\
\hline
\end{tabular}

Tablo 5 - Çelik Kazık Elemana ait Malzeme Parametreleri

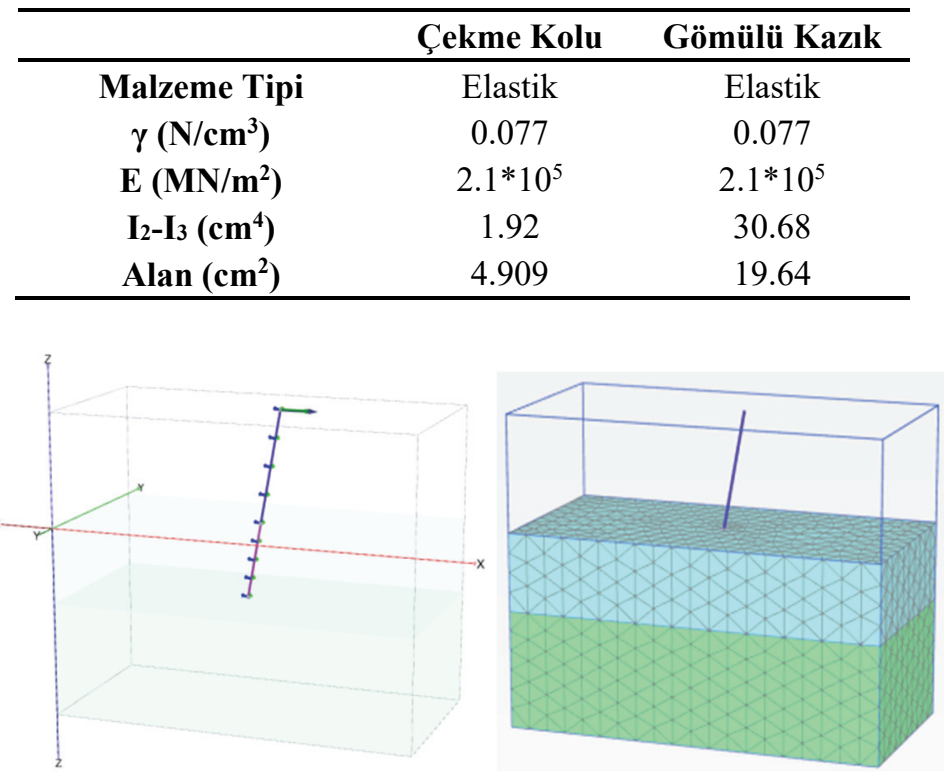

Şekil 6 - a) 3D Sonlu Elemanlar Modeli b) Sonlu Elemanlar A $\breve{g l}$ 


\subsection{Plaxis 2D ile Yapılan Analizler}

Yanal yüklü kazık probleminin 2 boyutlu analizi her ne kadar, geometrik ve yükleme koşulları açısından eksenel simetrik durumu bir arada taşımadığı için 3 boyutlu olarak ele alınması gereken bir geoteknik problem olsa da, modeli düzlem deformasyon koşullarda ele alarak yanal yük etkisi altında rijit bir duvar problemine dönüştürmek, literatüre de katk1 sağlayacak yeni bir bakış açısı sağlamıştır. Gerçek problem ile indirgenmiş 2 boyutlu problem arasındaki dönüşüm, sabit katsayılar ile gerçekleştirilmiş ve yaklaşımın bir fizibilite çalışması olarak ele alındığı ve geoteknik mühendisliği için farklı bir bakış açısı oluşturacağı düşünülmektedir.

Yanal yüklü eğik yerleşimli rijit kazıkların, homojen sıkı ve tabakalı zeminlerdeki davranışlarının 2 boyutlu olarak irdelenmesinde, dairesel kesitli kazık eleman, model bazında eksenel simetrik bir geometriyi yansıtsa da, yanal tekil yük sebebi ile sistem eksenel simetrik davranıştan çıkmaktadır. Bu sebeple, 2 boyutlu modellemede, yanal yüklü rijit dairesel kazıkların davranışı düzlem deformasyon koşullar altında analiz edilmiştir. İki boyutlu modelde, rijit kazık, birim genişlikte bir duvar eleman gibi tasarlanmış, yanal yük uygulanmasıyla, pasif zemin bölgelerinden aldığı dayanım ile taşıma gücüne ulaştığı kabul edilmiştir. Literatürdeki yaygın analitik çözüm yöntemleri de göz önüne alındığında, böyle bir yaklaşımın kullanılması, kazığın yanal yük taşıma kapasitesinin, sadece zemin bölgelerinden aldığı, pasif zemin basınçlarına bağlı olarak belirlenmesi ilkesi ile örtüşmektedir (Şekil 7).

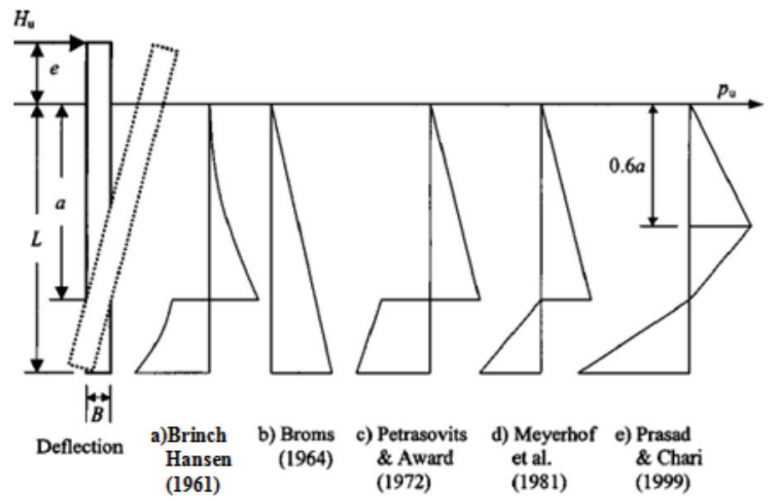

Şekil 7 - Araştırmacılar Tarafindan Önerilen Zemin Direnci Dağılımları (Zhang ve ark., 2005) [37]

İki boyutlu sayısal analiz için oluşturulan model geometrisi, deneysel çalışmalarda kullanılan küçük ölçekli model deney kasası boyutlarında hazırlanmıştır. Probleme ait sınır şartları girildikten sonra, zemin için Mohr-Coulomb malzeme modeli kullanılmıştır. Yapısal eleman modellenmesi için levha eleman kullanılmış ve çelik malzeme parametreleri tanımlanmıştır. Daire kesitli gömülü kazık ve çekme kolu için eşdeğer alan yöntemi kullanılarak, bu elemanlar rijit bir duvar olarak modellenmiştir. Yanal yük zemin yüzeyinden $30 \mathrm{~cm}$ yukarıdan etkiyen yatay tekil yük olarak uygulanmıştır (Şekil 8). 


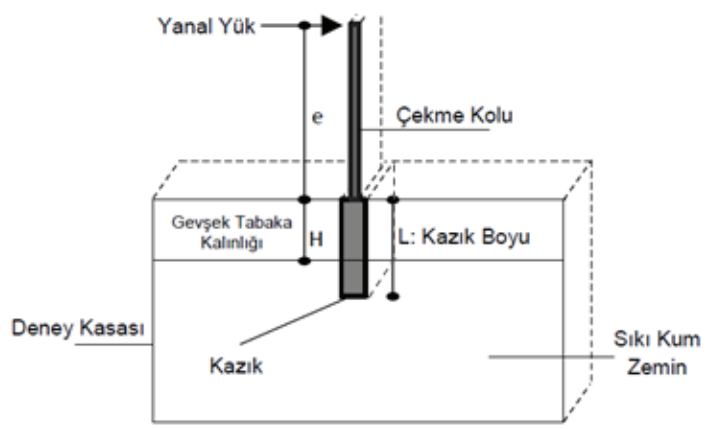

\section{Şekil 8 - Düzlem Deformasyon Koşullarında Problemin Şematik Görünümü} (Misir, 2015) [28]

Zemin ortamının iki boyutlu olarak modellenmesinin ardından, sistem, 15 düğümlü sonlu sayıdaki üçgen elemanlara bölünmüştür. Analizlerde, orta sıkılıktaki ağ düzeni seçilmiş ve başlangıç gerilme koşulu için "K0 Procedure" seçeneği ile sistemde efektif gerilme dağılımı tanımlanmıştır. Analiz aşamaları, başlangıç gerilme koşuluna ilave olarak, kazık ve çekme kolunun aktif halde olduğu ikinci adım ve tekil yükün uygulandığı üçüncü adım ile gerçekleştirilmiştir. Çalışmada iki boyutlu analizler, yaklaşık bir yöntem olarak ele alınmış ve deney sonuçları ile böyle bir yaklaşımın kabul edilebilir sonuçlar verip vermediği irdelenmiştir. Çalışmaya ait tipik bir sonlu elemanlar modeli ve problemin yükleme sonrası deforme olmuş hali Şekil 9'da verilmiştir.

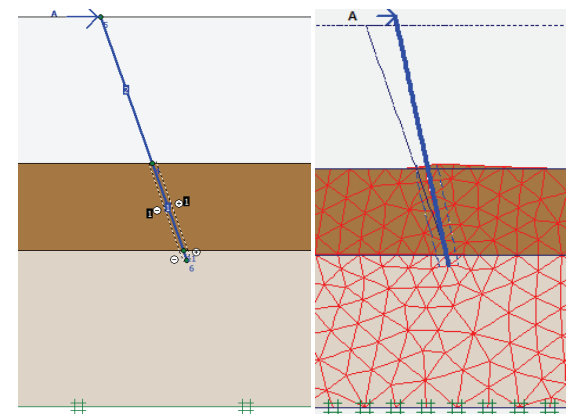

Şekil 9 - Düzlem Deformasyon Koşullarda Problemin Şematik Görünümü

\section{SONUÇLARIN KARŞILAŞTIRILMASI}

\subsection{Deney ve 3 Boyutlu Sayısal Analiz Sonuçlarının Karşılaştırılması}

Deney programında verilen model deney çalışmalarının tamamı, 3 boyutlu sayısal analizler ile modellenmiştir. Tüm setler için 3D analiz sonuçları deney sonuçları ile oldukça uyumlu çıkarken, bu çalışma kapsamında tipik bir deney seti olarak, kazık boyunun tamamının gevşek kum zemin içinde kaldığı (T20) durum ele alınmış, deney ve sayısal analizlerden elde edilen karşılaştırmalı yük-deplasman ilişkileri her kazık yerleşim açısı için ayrı ayrı detaylandırılarak Şekil 10'da sunulmuştur. Karşılaştırmalarda D, deney sonuçlarını, A ise sayısal analizlerden elde edilen sonuçları ifade etmektedir. 

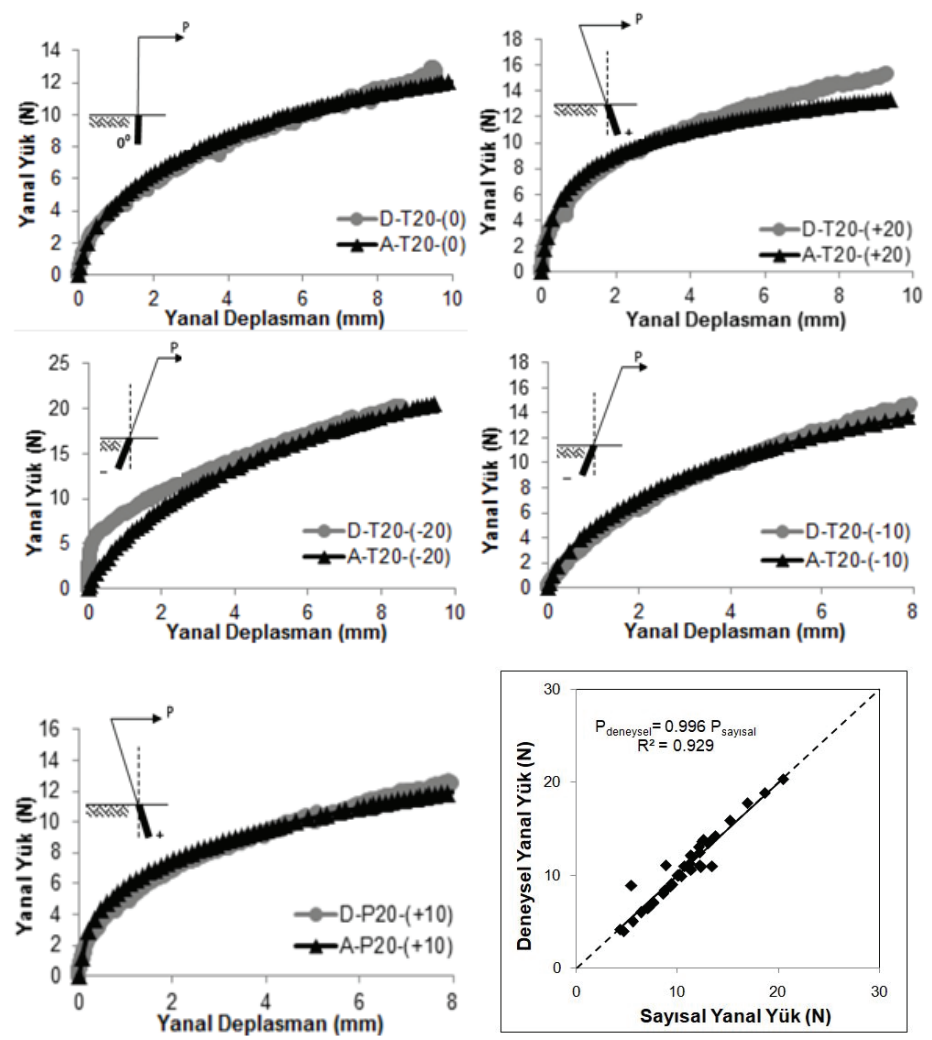

Şekil 10 - T20 Deney Seti için Deney ve Sayısal Analiz Sonuçlarının Karşılaştırılması
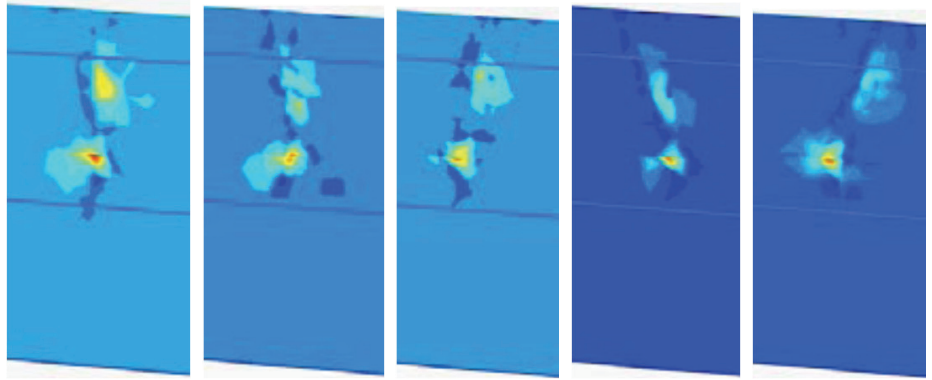

Şekil 11 - T20 Durumu için Yanal Gerilme Dăğlımları

Kazık boyunun \%100'ünün gevşek kum tabakası içinde yer aldığı (T20) ve beş farklı kazık yerleşim açısının kullanıldığı deney ve sayısal analiz setlerinden elde edilen yanal yük değerleri bir arada değerlendirildiğinde, kullanılan 40 adet deney datası $\mathrm{y}=\mathrm{x}$ doğrusuna oldukça paralel ve elde edilen ilişki, $\mathrm{R}=0.964\left(\mathrm{R}^{2}=0.929\right)$ gibi yüksek bir korelasyon katsayısına sahiptir. 
Sayısal analiz sonuçları yük deplasman ilişkisi bakımından incelendikten sonra, yanal yük etkisi ile rijit kazık etrafında yer alan zemin bölgesinde oluşan yanal gerilmelerin dağılımları da, Plaxis 3D program çıktıları üzerinden incelenmiştir. Kazık boyunun \%100'ünün gevşek kum zemin içerisinde olduğu tabakalı zemin durumuna ait yanal gerilme dağılımları Şekil 11 'de verilmişstir.

Analizlerden elde edilen yanal gerilme dağılımları incelendiğinde, dönme noktası üstü kazık ön yüzü ile dönme noktası altı kazık arka yüzünde oluşan pasif bölgeler ile bu bölgelerin aksi yönünde kalan ve çekme gerilmelerinin oluştuğu bölgeler açıkça görülmektedir. Kazık boyunun tamamının gevşek kum zemin içerisinde kaldığı ve kazık tabanının sıkı kum zemine oturduğu yerleşimde, maksimum yanal gerilme değeri kazık tabanına yakın bölgede yoğunlaşmaktadır (Şekil 11). Bu durum kazı̆̆ın temas halinde olduğu zemin bölgesinde, rijitlikleri birbirinden farklı iki ayrı zeminin yer aldığı durumda, en büyük yatay gerilmelerin, rijitliğin fazla olduğu zemin bölgesinde yoğunlaşması ile açıklanabilmektedir.

\subsection{Deney ve 2 Boyutlu Sayısal Analiz Sonuçlarının Karşılaştırılması}

5 farklı zemin koşulu ve 5 farklı kazık yerleşim açısında gerçekleştirilen iki boyutlu sayısal analiz sonuçları, deney sonuçlarından elde edilen yük-deplasman eğrileri ile karşılaştırıldığında benzer non-lineer forma sahip olduğu görülmektedir. Ancak, iki boyutlu analizlerden elde edilen yük değerleri, deneylerden elde edilen değerlere kıyasla oldukça
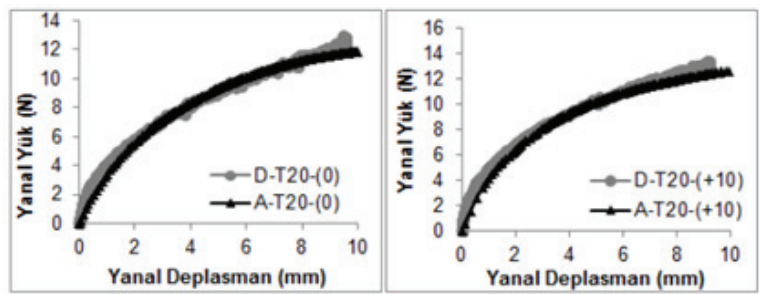

a. $\left(0^{\circ}\right)$

b. $\left(+10^{\circ}\right)$
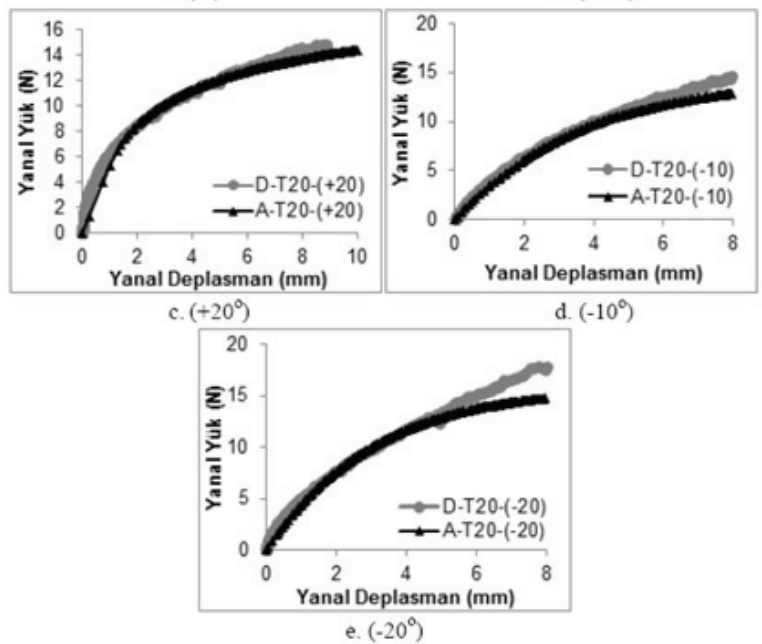

Şekil 12 - T20 Setinde 2D Analiz ve Deney Sonuçlarının Karşılaştırması 
küçük mertebelerde kalmaktadır. Bu nedenle, iki boyutlu sayısal analizler ile sonuca gidilebilecek uygun bir yaklaşımın geliştirilebilmesi amacıyla, iki boyutlu sayısal analizlerden elde edilen yük değerleri, deney eğrileri ile örtüşecek ve ortalama bağıl hata minimum kalacak şekilde uygun birer sabit katsayı ile çarpılmıştır.

Deney ve 2-D sayısal analizlerden elde edilen karşılaştırmalı yük-deplasman grafikleri 5 farklı kazık yerleşim açısı için gevşek kum zemin tabaka kalınlığının \%100 olduğu tabakalı zemin deney seti için Şekil 12'de verilmiştir. Tüm zemin ve kazık yerleşim açıları için, iki boyutlu sayısal analiz sonucunu deneyden elde edilen yük-deplasman eğrisine yaklaştıran katsayılar, kazık yerleşim açısının bir fonksiyonu olarak yüksek korelasyon katsayısı ile $(\mathrm{R}=0.99)$ tanımlanmıştır (Şekil 13a-b).

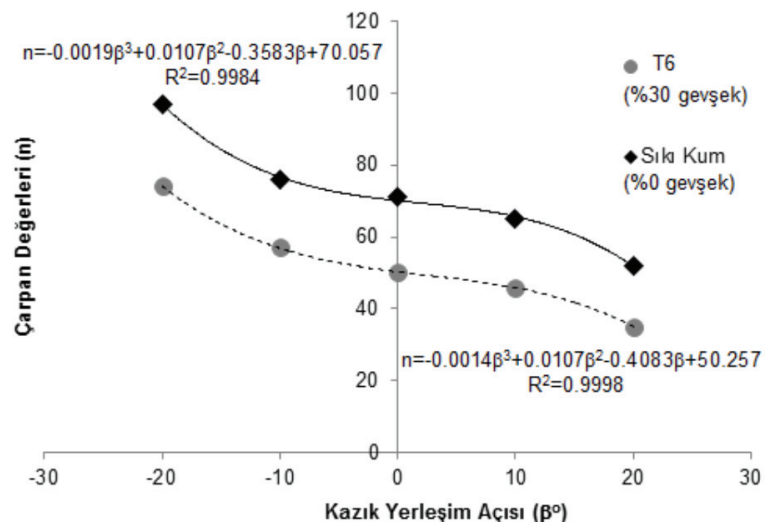

Şekil 13a - Homojen ve Tabakalı Zemin Durumları için Çarpan Değerleri (Sıkı Kum ve T6)

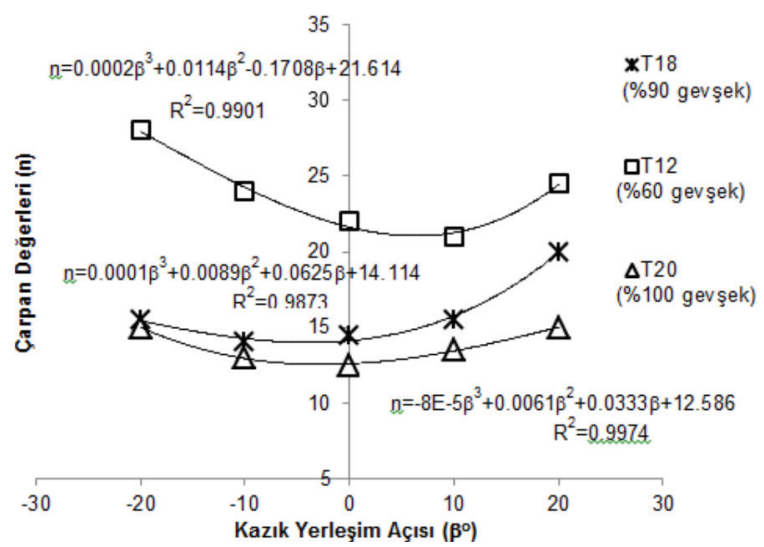

Şekil 13 b - Homojen ve Tabakalı Zemin Durumları için Çarpan Değerleri (T12, T18 ve T20)

Bununla birlikte; bu çalışma kapsamında tariflenen yaklaşımın tutarlılığ 1 , benzer koşullarda elde edilmiş deney sonuçları ile karşılaştırılarak değerlendirilebilir. Bu amaçla, homojen sıkı kum zemin koşulunda gerçekleştirilen ve ilgili denklemlerin türetilmesinde kullanılmayan, 
negatif ve pozitif yönlü $15^{\circ}$ 'lik ara açı değerleri için elde edilen deney sonuçları, iki boyutlu analizler için öne sürülen katsayıların geçerliliğini test etmek amacı ile kullanılmıştır (Şekil 14a). Sıkı kum zeminde pozitif ve negatif yönlerde $15^{\circ}$ açı ile yerleştirilen kazık için 2 boyutlu sonuçları deney sonuçlarına yaklaştıran katsayılar sırası ile 60.7 ve 84.2 olarak hesaplanmıştır. Deneysel çalışmalar ve katsayılar ile desteklenmiş 2 boyutlu analiz sonuçları arasında oldukça yakın bir ilşki elde edilmiş ve aynı yanal harekete karşı gelen deneysel ve tahmin edilen yanal yük değerleri arasında (R) 0.966 gibi yüksek bir korelasyon katsayısı elde edilmiştir (Şekil 14b).

a)

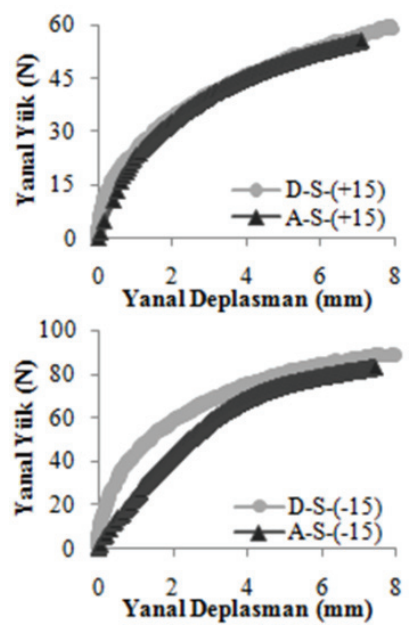

b)

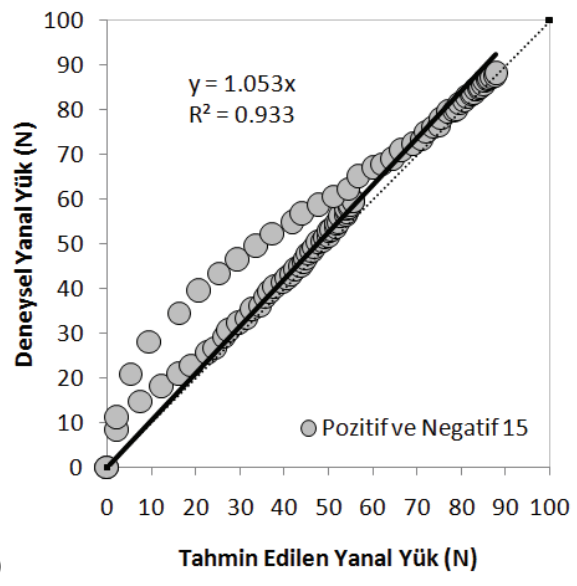

Şekil 14 - a) İki Boyutlu Analizler için Kullanılan Katsayıların Doğrulanması, b) Deney ve 2B Analiz Sonuçlarından Elde Edilen Yanal Yük Değerlerinin Karşılaştırılması

Tablo 6 - Çelik Kazık Elemana ait Malzeme Parametreleri

\begin{tabular}{|c|c|c|c|c|c|c|}
\hline \multirow{3}{*}{ Deney Adı } & \multicolumn{6}{|c|}{ Yanal Deplasman Miktarı } \\
\hline & \multicolumn{2}{|c|}{$\begin{array}{c}\% 5 \\
2.50 \mathrm{~mm}\end{array}$} & \multicolumn{2}{|c|}{$\begin{array}{c}\% 10 \\
5.0 \mathrm{~mm}\end{array}$} & \multicolumn{2}{|c|}{$\begin{array}{c}\% 15 \\
7.50 \mathrm{~mm}\end{array}$} \\
\hline & Analiz & Deney & Analiz & Deney & Analiz & Deney \\
\hline \multirow{2}{*}{ S- $(+15)$} & 34.84 & 37.28 & 47.41 & 49.58 & 54.01 & 58.08 \\
\hline & \multicolumn{2}{|c|}{$\% 6.5$} & \multicolumn{2}{|c|}{$\% 4.4$} & \multicolumn{2}{|c|}{$\% 7.0$} \\
\hline \multirow{2}{*}{ S-(-15) } & 51.96 & 61.57 & 75.98 & 79.48 & 83.80 & 87.77 \\
\hline & \multicolumn{2}{|c|}{$\% 15.6$} & \multicolumn{2}{|c|}{$\% 4.4$} & \multicolumn{2}{|c|}{$\% 4.5$} \\
\hline
\end{tabular}

Rijit kazık çapının 50 mm olduğu durumda kazık başında meydana gelen 3 farklı yanal ötelenme oranları için ( $\mathrm{s} / \mathrm{D}=\% 2.5, \% 5.0$ ve $\% 7.5)$, model deney ve 2 boyutlu sayısal analiz sonuçlarından elde edilen yanal yük değeleri karşılaştırıldığında, hata oranları pozitif yerleşimli kazık durumunda ortalama \%5.97, negatif yerleşimli kazık durumunda ise $\% 8.17$ 
mertebelerinde elde edilmiştir. İlgili yöntemin bir yaklaşım metodu olduğu düşünüldüğünde, sonuçların oldukça umut verici olduğu söylenebilir (Tablo 6).

Elde edilen sonuçlara göre, gerçek çözümünün üç boyutlu olarak elde edilmesi gereken yanal yük altındaki kısa kazık problemi, iki boyuta indirgendiğinde, problem önemli kabuller içererek boyut değiştirmekte ve yanal yönde şerit yük altındaki rijit bir duvar problemine dönüşmektedir. Ancak, iki boyutlu analiz sonuçlarında gerçek problem ile benzer davranışın gözlenmesi ve literatürde bu tarz problemlerin iki boyutlu olarak incelenebiliyor olması (Kok ve Huat, 2008 ve Maouche ve ark., 2009) [38-39] dikkate alındığında, problemin iki boyuta indirgemesiyle elde edilen sonuçların kabul edilebilir sınırlar içerisinde olduğu görülmüştür.

\section{SONUÇLAR}

Bu çalışmada, yanal yük etkisindeki tekil kazığın, homojen ve tabakalı zemin koşullarında, deney kasası içerisine düşey ve eğik olarak yerleştirilmesi durumlarında yanal yük taşıma kapasiteleri araştırılmıştır. Deneylerden elde edilen sonuçlar, sonlu elemanlar yöntemi ile non-lineer analiz yapan iki ve üç boyutlu PLAXIS programından elde edilen sonuçlar ile karşılaştırılmıştır.

Elde edilen sonuçlardan öne çıkan hususlar, aşağıda sunulmuştur.

- Deney çalışmaları iki ve üç boyutlu olarak Plaxis programı ile modellenmiştir. Üç boyutlu modellemelere ait analizler deney setleri için gerçekleştirilmiş olup, tipik bir deney setine (T20) ait sonuçlar sunulmuştur. Karşılaştırmalardan deney ve üç boyutlu sayısal analiz sonuçlarının oldukça uyumlu olduğu görülmüştür.

- Üç boyutlu sayısal analizlerden elde edilen yanal gerilme dağılımları incelendiğinde, sistemin yük performansında etkili olan dönme noktası üstü kazık ön yüzü ile dönme noktası altı kazık arka yüzünde oluşan pasif bölgeler ile, bu bölgelerin aksi yönünde kalan ve çekme gerilmelerinin oluştuğu bölgelerdeki dağılımlar açık bir şekilde elde edilmiştir.

- Kazık ile temas halinde olan zemin bölgesinde, göreceli olarak rijitlikleri birbirinden farklı iki zeminin yer alması durumunda, rijitliği daha fazla olan zeminde oluşan yanal gerilme dağılımı daha belirgin olurken, üst tabakada yer alan gevşek kum zeminde yanal gerilme dağılımı daha küçük mertebelerde kalmaktadır. Gevşek tabaka kalınlığının artması sonucu, bu bölgede, mevcut sürşarj yükünün etkisi ile yanal gerilmelerde bir artış olsa da, maksimum yanal gerilme değeri, nispeten rijitliği yüksek olan zemin tabakası içerisinde kalmaktadır.

- Yanal yüklü kazık probleminin iki boyutlu olarak modellenmesi, geoteknik mühendisliğinde yaygın olarak kullanılan bir yaklaşım değildir. Bu çalışmada ilk defa, iki ve üç boyutlu (gerçek problem) model arasındaki dönüşüm farkı, sabit katsayılar kullanılarak aşılmıştır.

- İki boyutlu analizler ile elde edilen yük-deplasman ilişkisi, deney sonuçları ile uyumlu olacak şekilde, uygun birer katsayı ile çarpılmıştır. Bu katsayılar arasında kurulan sistematik ilişki ile katsayı belirlemede kullanılmayan, homojen sıkı zemin koşulunda gerçekleştirilen $-15^{\circ}$ ve $+15^{\circ}$ lik ara açı değerleri için yaklaşımın doğruluğu test edilmiştir. Hesaplanan katsayılar kullanılarak elde edilen analiz sonuçları ile deney 
sonuçları arasında yeterli bir uyumun oluştuğu gözlenmiştir. Bu durum; kullanılan yaklaşımın kabul edilebilir doğrulukta sonuçlar verdiğini göstermektedir.

\section{Semboller}

$\mathrm{c}$

: kohezyon

$\mathrm{D}_{\mathrm{f}} \quad$ : kazık gömülü boyu

D : gömülü kazık çapı

$\mathrm{D}_{\mathrm{PA}} \quad$ : çekme kolu çapı

DT : deplasmanölçer

e : eksantrisite

E : Elastisite modülü

$\mathrm{E}_{\text {inc }} \quad:$ artımsal elastisite modülü

$\mathrm{E}_{\mathrm{ref}} \quad$ : başlangıç elastisite modülü

H : gevşek kum tabaka kalınlığg

$\mathrm{I}_{2-3} \quad$ : dairesel kesitte atalet momenti

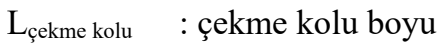

n : çarpan değerleri

$\mathrm{P} \quad$ : yanal yük

R : korelasyon katsayısı

$\mathrm{R}_{\mathrm{d}} \quad$ : dönme noktası derinliği

$\mathrm{R}^{2} \quad$ : determinasyon katsayısı

S : homojen sıkı kum zemin

$\mathrm{T} \quad$ : tabakalı zemin

U : yanal deplasman

$\mathrm{y}_{\text {ref }} \quad:$ referans derinliği

$\beta \quad$ : kazık yerleşim açısı

$\gamma_{\mathrm{n}} \quad:$ doğal birim hacim ağırlık

$\checkmark \quad$ : poisson oran1

$\phi \quad$ : içsel sürtünme açısı

$\psi \quad$ : dilatasyon açısı 


\section{Kaynaklar}

[1] Poulos, H.G., Davis, E.H., Pile Foundation Analysis and Design, John Wiley \& Sons. Inc., New York, N.Y., 1980.

[2] Brinch-Hansen, J., The Ultimate Resistance of Rigid Piles Against Transversal Forces, The Danish Geotechnical Inst., Bulletin No:12, 5-9, 1961.

[3] Broms, B.B., Lateral Resistance of Piles in Cohesive Soils, Journal of Soil Mechanics and Foundation Engineering Division, ASCE, 90(2), 27-63, 1964a.

[4] Broms, B.B., Lateral Resistance of Piles in Cohesionless Soils, Journal of the Soil Mechanics and Foundations Division, 90 (3): 123-156, $1964 \mathrm{~b}$.

[5] Zomorodian, S.M.A., Dehghan, M., Lateral Resistance of a Pile Installed Near a Reinforced Slope. Int. J. of Physical Modelling in Geotechnics, 11(4), 156-165, 2011.

[6] Helm, J., Suleiman, M., Measuring Soil-Structure Interaction on Laterally Loaded Piles with Digital Image Correlation. Full Field Measurements and Identification in Solid Mechanics, Procedia IUTAM, (4), 66-72, 2012.

[7] Rahimi, M.R., Bargi, K., Efficient Arrangement of Batter Piles of a Pile-Supported Wharf in Sand. Electronic J. of Geotech. Eng., (15), 729-738, 2010.

[8] Vu, A.T., Matsumoto, T., Kobayashi, S., Nguyen, T., Model load tests on battered pile foundations and finite-element analysis. Int. J. of Physical Modelling in Geotechnics, http://dx.doi.org/10.1680/jphmg.16.00010, 2016.

[9] Vu, A.T., Matsumoto, T., Kobayashi, S., Shimono, S., Experimental Study on Pile Foundations having Batter Piles Subjected to Combination of Vertical and Horizontal Loading at 1-g Field. Geotechnical Eng. J. of the SEAGS \& AGSSEA, 48(3), 12-24, 2017.

[10] Albusoda, B.S., Alsaddi, A.F., Experimental study on performance of laterally loaded plumb and battered piles. J. of Eng., 23 (9), 23-37, 2017.

[11] Kyung, D., Lee, J., Interpretative Analysis of Lateral Load-Carrying Behavior and Design Model for Inclined Single and Group Micropiles. J. of Geotechnical and Geoenvironmental Eng., Vo. 144, No:1, 1-11, 2018.

[12] Reddy, K.M., Ayothiraman, R., Experimental Studies on Behavior of Single Pile under Combined Uplift and Lateral Loading. Journal of Geotechnical and Geoenvironmental Engineering, Vol. 141, No: 7, 2015.

[13] Bisaws, S.K., Mukherjee, S., Chakrabarti, S., De, M., Experimental investigation of free head model piles under lateral load in homogenous and layered sand. Int. J. of Geotechnical Engineering, Vol. 9, No: 4, 363-378, 2015.

[14] Hai-Lin, S.M., Lusu Ni, S., Muhannad T. Suleiman, A.M., Anne Raich, A.M., Interaction between Laterally Loaded Pile and Surrounding Soil. Journal of Geotech. Geoenviron. Engineering, Vol. 141, No:4, 1-11, 2014. 
[15] Kwon, O.K., Kim, J.B., Kweon, H.M., An Experimental Study on the Resistance and Movement of Short Pile Installed in Sands Under Horizontal Pullout Load. Int. J. of Naval Architecture and Ocean Eng., 6, 87-97, 2014.

[16] Manoppo, F.J., Behaviour of the Ultimate Bearing Capacity of Single Flexible Batter Pile Under Horizontal Loads in Homogeneous Sand, Dinamika Teknik Sıpıl, 10(2): 116-119, 2009.

[17] Zhang, L., Mcway, M.C., Lai, P.W., Centrifuge Modelling of Laterally Loaded Single Battered Piles in Sands, Canadian Geotechnical J., 36(6): 1074-1084, 1999.

[18] Plaxis 2D, Manuals. Plaxis Finite Element Code for Soil and Rock Analysis, 2D Version 8.6. (Edited by Brinkgreve R.B.J., Broere W. And Waterman D.) Delft University of Technology \& Plaxis, The Netherlands, 2004.

[19] Plaxis 3D, Manuals. Plaxis Finite Element Code for Soil and Rock Analysis, 3D (Edited by Brinkgreve R.B.J., Broere W. And Waterman D.) Delft University of Technology \& Plaxis, The Netherlands, 2013.

[20] Chari, T.R., Meyerhof, G.G., Ultimate capacity of rigid single piles under inclined loads in sand. Canadian Geotechnical J., (20), 849-854, 1983.

[21] Matlock, H., Reese, L.C., Generalized solutions for laterally loaded piles. J. Soil Mech. Found. Div., Am. Soc. Div. Eng., 86 (5), 63-91, 1960.

[22] Karatzia, X., Mylonakis, G., Horizontal response of piles in inhomogeneous soil simple analysis. II. International Conference on Performance Based Design in Earthquake Geotehnical Engineering, 2012.

[23] Tomlinson, M.J., Foundation Design and Construction, 7. Bask1, Prentice Hall, 2001.

[24] Santana, A., Aznarez, J.J., Padron, L.A., Maeso, O., A criterion to assess the relevance of structural flexibility on the seismic response of large buried structures. Soil Dynamics and Earthquake Engineering, (106), 243-253, 2018.

[25] Giannakou, A., Gerolymos, N., Gazetas, G., On the Dynamics of Inclined Piles. $10^{\text {th }}$ Int. Conf. on Piling and Deep Foundations, Amsterdam/Netherlands, May 2006.

[26] Badry, P., Satyam, D.N., The Effect of the L/D Ratio of Pile Group Using the Equivalent Pier Method Including Interaction. Int. Congress and Exhibition "Sustainable Civil Infrastructures: Innovative Infrastructure Geotechnology", July 2018, 157-170, 2018.

[27] Uncuoğlu, E., Kohezyonsuz Zeminlerdeki Kazıkların Yatay Yük ve Moment Etkisi Altındaki Davranışlarının Analizi, Doktora Tezi, 277s, Çukurova Üniversitesi, Adana, 2015.

[28] Misir, G., Yanal Yüklü Kazıkların Farklı Zemin Ve Yükleme Koşullarında Analizi, Doktora Tezi, 195s, Çukurova Üniversitesi, Adana, 2015.

[29] Karayolu Trafik Güvenliğinin Sağlanması Yönünden, Yolun Yapısında Yapılacak Her Türlü Çalışmalarda Alınacak Tedbirlerle Karayolu Dışında, Kenarında veya Üzerindeki Diğer Levhalar, Işıklar ve İşaretlemeler Hakkında Yönetmelik, 1985. 
[30] Rajashree, S.S., Sitharam, T.G., Nonlinear Finite-Element Modeling of Batter Piles Under Lateral Load. J. of Geotech. and Geoenv. Eng., (127), 604-612, 2001.

[31] Yang, Z., Jeremic, B., Study of Soil Layering Effects on Lateral Loading Behavior of Piles. J. of Geotech. and Geoenv. Eng., (131), 762-770, 2005.

[32] Karthigeyan, S., Ramakrishna, V.V.G.S.T., Rajagopal, K., Numerical Investigation of the Effect of Vertical Load on the Lateral Response of Piles. J. of Geotechnical and Geoenvironmental Eng., (133), 512-521, 2007.

[33] Achmus, M., Abdel-Rahman, K., Thieken K., Behavior of Piles in Sand Subjected to Inclined Loads. Juan-Les-Pins, France, 2009.

[34] Maouche, H., Boumekik, A., Sbartai, B., Numerical Analysis of the Response of a Single Pile Embedded in Non Linear Uniform Soils. Int. Review of Mechanical Engineering, 3(5), 674-678, 2009.

[35] Sawant, V.A., Shukla, S.K., Finite Element Analysis for Laterally Loaded Piles in Sloping Ground. Coupled Systems Mech., 1(1), 59-78, 2012.

[36] Mroueh, H., Shahrour, I., Numerical Analysis of the Response of Battered Piles to Inclined Pullout Loads. International Journal for Numerical and Analytical Methods in Geomechanics, DOI: 10.1002/nag.765, 2008.

[37] Zhang, L., Silva, F., Grismala, R., Ultimate Lateral Resistance to Piles in Cohesionless Soils, J. of Geotech. and Geoenv. Eng., 131(1): 78-83, 2005.

[38] Kok, S.T., Huat, B.B.K., Numerical Modeling of Laterally Loaded Piles, American Journal of Applied Sciences, 5(10): 1403-1408, 2008.

[39] Maouche, H., Boumekik, A., Sbartai, B., Numerical Analysis of the Response of a Single Pile Embedded in Nonlinear Uniform Soils, International Review of Mechanical Engineering, 3(5): 674-678, 2009. 
